\title{
A Stress-test for Democracy: Analysing the New Zealand Government's Response to the COVID-19 Pandemic from a Constitutional Perspective
}

\author{
Dr Myra E.J.B. Williamson ${ }^{1}$
}

\begin{abstract}
This article explores the New Zealand Government's response to the COVID-19 coronavirus pandemic through a legal and constitutional lens. It adopts an essentially doctrinal analysis in describing the response but intertwines a comparative law thread, to draw selected comparisons with how other governments have responded. It offers some political, demographical and historical insights to provide background information for non-New Zealand readers. The article aims to provide a comprehensive view of New Zealand's constitutional arrangements and how they have impacted on the Government's response to COVID-19 as well as a critical analysis of that response by assessing the effectiveness of various measures adopted by the New Zealand Government. The article consists of six sections. Section one provides an introduction to New Zealand's constitutional framework including some demographic information for non-New Zealand readers. Section two describes the New Zealand Government's overall response to the COVID-19 pandemic. Section three discusses the declaration of a national state of emergency. Section four examines the Parliamentary oversight mechanism known as the "Epidemic Response Committee". Section five explores the role of the media and the importance of upholding the right to freedom of expression when responding to the pandemic. Finally, section six draws out some overall recommendations for New Zealand and other countries to consider when moving forward and preparing for the next pandemic.
\end{abstract}

Keywords: COVID-19 coronavirus, New Zealand's constitutional arrangements, freedom of expression and COVID-19, the role of the media and COVID-19, national state of emergency and COVID-19, the Epidemic Response Committee, parliamentary oversight of the executive, COVID-19 investigatory body

1 BA, LLB Hons (First Class), LLM Hons (First Class), PhD, PGCertTTL. Preferred email address for correspondence with the author: drmyrawilliamson@gmail.com. The "last accessed" date for all websites cited herein is 25 May 2020. All dates, facts, figures, websites and sources were correct as at "the time of writing", which is 25 May 2020. British spelling is utilized throughout the paper. 


\section{Introduction}

At the end of 2019, a virus now officially known as COVID-19, and previously known as the "2019 novel corona virus", emerged in Wuhan, China. ${ }^{2}$ The virus was supposedly limited to China throughout December 2019 and into early 2020. On 12 January 2020, every known case was inside China. Then on 13 January, a case was recorded in Thailand, then in South Korea and the United States. ${ }^{3}$ In a few days the number of countries reporting cases increased and just two months later, on 12 March 2020, the World Health Organization (WHO) announced that the outbreak was officially a pandemic. ${ }^{4}$

At the time of writing, it is fairly widely accepted that the source of the virus was probably the "wet markets" in Wuhan, specifically, the Huanan Seafood Wholesale Market. There is currently some speculation in the media that the virus originated in bats sold at that market. ${ }^{5}$ That is a widely circulated theory (as of 25 May 2020) but it is not unanimously accepted. The Daily Mail newspaper reported on 17 May 2020 that in a landmark study (which has not yet been peer-reviewed), specialist biologists conclude that the virus detected in the Wuhan market was brought in by human transmission. ${ }^{6}$ The scientific paper asserts that the strain of the virus detected in the markets "was already pre-adapted to human transmission". ${ }^{7}$ Aside from that scientific study,

2 World Health Organization, "Naming the coronavirus disease (COVID19) and the virus that causes it" (online, 2020) available at: <https://www.who.int/emergencies/diseases/novel-coronavirus-2019/ technical-guidance/naming-the-coronavirus-disease-(covid-2019)-and-the-virus-that-causes-it> .

3 Radio New Zealand, "COVID-19: The countries without the deadly virus" RNZ (online ed, 3 April 2020) available at: https://www.rnz.co.nz/news/world/413417/covid-19-the-countries-without-thedeadly-virus>.

4 World Health Organization, "WHO announces COVID-19 outbreak a pandemic" 12 March 2020, available at: <http://www.euro.who.int/en/health-topics/health-emergencies/coronavirus-covid-19/ news/news/2020/3/who-announces-covid-19-outbreak-a-pandemic $>$.

5 Dina Fine Marron, "'Wet markets' likely launched the virus. Here's what you need to know" National Geographic (online ed, 15 April 2020) available at: <https://www.nationalgeographic.com/ animals/2020/04/coronavirus-linked-to-chinese-wet-markets/>

6 Ian Birrell, "Coronavirus did NOT come from animals in Wuhan market: Landmark study suggests it was taken into the area by someone already infected" 17 May 2020, Daily Mail (online ed, 17 May 2020) available at: <https://www.dailymail.co.uk/news/article-8326823/Landmark-study-Virus-didntcome-animals-Wuhan-market.html>.

7 Shing Hei Zhan, Benjamin E Deverman and Yujia Alina Chan, "SARS-COV-2 is well-adapted for humans. What does this mean for re-emergence" 2 May 2020, bioRvix, available at: https://www.biorxiv. org/content/10.1101/2020.05.01.073262v1.full.pdf DOI: https://doi.org/10.1101/2020.05.01.073262. Note that this scientific paper is a pre-print manuscript made available by the authors online and it has not yet been peer-reviewed. Zhan, Deverman and Chan conclude at page 12 of their paper that the origin of the virus samples from the Wuhan market is likely to be human: "SARS-CoV-2 genomes in the market samples were most likely from humans infected by SARS-CoV-2 who were vendors or visitors at the market. If intermediate animal hosts were present at the market, no evidence remains in the genetic samples available." 
the US President Donald Trump has asserted that the virus perhaps originated in a laboratory at the Wuhan Institute of Virology, and that the "wet market" story was (according to this line of thinking) part of an alleged cover-up by the Chinese Government to deflect attention from the allegedly "real" source of the virus. ${ }^{8}$ At the time of writing, the source of COVID-19 is still being investigated and no consensus on its origins has yet emerged. This article does not attempt to resolve that controversy, merely to note that it currently exists. In addition, it is noted that approximately 100 countries have called for an investigation into not only the origins of the virus, but how the WHO reacted and handled the response. ${ }^{9}$

Indeed, this article does not address the current controversy over the source or containment of the COVID-19 virus, because it doesn't need to: regardless of the source of the virus and regardless of who is ultimately to blame for its lack of containment in China, the reality is that COVID-19 developed into a global health crisis in 2020, one which will likely have more far-reaching effects than the global financial crisis of 2007-2008. Whatever the cause, whoever's to blame, it is at least clear that COVID-19 poses global challenges. This paper focuses mainly on the response of the New Zealand Government, but in this hyper inter-connected global environment, the research and observations offered herein may be of interest to many governments, academics and policymakers, since a global pandemic calls for global solutions. ${ }^{10}$

\section{Structure, methodology, limitations and originality of this article}

The COVID-19 pandemic is being-and for years to come will beanalysed from many different angles. Scholars from disciplines such as health, medicine, education, the environment, human rights, gender studies, religion, psychology, economics, social justice, law and politics will give their perspectives, and will research and write on COVID-19 for the foreseeable future. Scholars will consider the long-term effects of COVID-19, what can be learnt from individual governmental responses and how the world can prepare

8 For examples of where this theory has been discussed in the media see: Oli Smith, "Classified leaks show wet markets used to cover up role of Wuhan virus lab in COVID-19" Express.co.uk (online ed, Express, 16 April 2020) available at: <https://www.express.co.uk/news/world/1269710/China-coverup-conspiracy-Wuhan-wet-market-virus-lab-COVID-19-wet-markets-latest $>$.

9 James Griffin, "China has been trying to avoid fallout from coronavirus. Now 100 countries are calling for an investigation" $C N N$ (online ed, 18 May 2020) available at: $<$ https://edition.cnn.com/2020/05/18/ asia/china-world-health-assembly-investigation-intl-hnk/index.html>.

10 "Almost" every country because at the time of writing (25 April 2020), there is a handful of countries in the South Pacific and Asia who have reported no cases of COVID-19: see Catherine Putz, "Where in the world are there no Coronavirus cases?" The Diplomat (online ed, 3 April 2020) available at: https:// thediplomat.com/2020/04/where-in-the-world-are-there-no-coronavirus-cases/. 
better for the next pandemic. The overall objective of this paper is to examine the response to COVID-19 from just a constitutional and legal perspective, supported where necessary by historical, theoretical and comparative legal analysis. It examines some of the key constitutional aspects of the New Zealand Government's COVID-19 response. It adopts the following structure to address a small selection of constitutional issues that have arisen from the COVID-19 pandemic.

Section one will provide a brief introduction to New Zealand's constitutional framework. Section two will describe the New Zealand Government's overall response to the COVID-19 pandemic. Section three will discuss the declaration of a state of emergency, the powers that were activated by that declaration, and how those powers were used. In section four the paper will analyse the Parliamentary oversight mechanism created by the establishment of the "Epidemic Response Committee", chaired by the Leader of the Opposition, to scrutinise Governmental action whilst Parliament was adjourned. In section five the role of the press in holding the Government to account will be examined. Finally, in section six a brief conclusion of the constitutional lessons that might be learnt from the Government's response will be offered.

The methodology adopted in this article is largely a doctrinal, black letter law approach, describing the legal and constitutional aspects of the New Zealand Government's response by reference to both constitutional theory and statute law. However, it will also have a comparative thread running through it, drawing comparisons and parallels with other countries laws and responses, when that is useful to throw light on respective governments' responses. This is a global pandemic and every country should be casting a careful eye on the response of other countries, to see what lessons they can learn and what mistakes they can avoid in the future. In addition - and in direct response to the suggestions of peer-reviewers - the article also provides at the outset some demographic and political information about New Zealand, which helps to place the COVID-19 response in a social context.

In terms of limitations, it is acknowledged at the outset that an unavoidable problem in writing about an unfolding event is that statistics, which are correct at the time of writing, will be inevitably out of date by the time of publication. Every effort has been made to ensure that statistics stated herein were correct at the time of post-peer review revision (25 May 2020). ${ }^{11}$ Likewise, making

11 The first manuscript was completed and submitted on 25 April 2020; the revisions, after the double blind peer review process, were completed on 25 May 2020. Thus, all dates and events are correct as of the latter date. 
statements about the apparent success that New Zealand has so far enjoyed in eliminating COVID-19 could quite easily be overtaken by subsequent events. The risk of a second wave of the virus (and even some isolated cases if not a second wave) certainly exists - especially once New Zealand's borders are reopened beyond the current situation where only New Zealand citizens and permanent residents are allowed to enter - and there is no way to predict whether the current success will be sustained. Once New Zealand's borders are reopened to Australia and then the rest of the world, it is highly likely that there will be new cases of COVID-19. However, bearing those limitations in mind, it is still worth writing about the response when it is fresh in everyone's minds. The assertions made herein were correct, to the author's knowledge, at the time that this article was submitted for publication after all peer-review and manuscript revision processes were completed, on 25 May 2020.

The originality factor of this paper is high, driven by the fact that due to the nature of the unfolding global health crisis, and its inherent newness, there is very little published and peer-reviewed research in the humanities on COVID-19. There have been media reports and opinions expressed on various aspects of governmental responses, but to date - and to this researcher's knowledgethere are no published peer-reviewed articles on the constitutional and legal aspects of the New Zealand Government's response to COVID-19. Thus, the content and approach of this paper is entirely original. It will hopefully create a basis for further analysis once the pandemic has been brought under control and there is more time to calmly and carefully examine all aspects of the New Zealand Government's (and other governments') response to COVID-19. This article does not attempt to be the "last word" on the New Zealand Government's response to COVID-19, in fact, it is merely endeavouring to be the first few words in what will likely be a rich area for future scholarship.

\section{Section 1. An introduction to New Zealand and its constitutional framework}

Some background information about New Zealand might be helpful to any reader who is not already familiar with the demographics of this South Pacific nation, nor with its rather unusual constitutional framework. Population information is provided first, followed by an overview of the country's constitutional arrangements. 


\section{Total population and ethnicity}

As of March 2020, the resident population of New Zealand is 5 million people. ${ }^{12}$ New Zealand's population has increased from approximately 800,000 in 1910 to surpassing the 5 million mark this year. New Zealand conducts a survey of its entire population every five years, and has done so since the very first census was held in 1851. That census only counted the European population, and found that the population of New Zealand was a mere 26,707. ${ }^{13}$ Back in 1908, the population mainly consisted of settlers from the United Kingdom (since New Zealand was a British colony) and the indigenous Maori population was at about five percent. Nowadays, 16.5 percent of the total population identify as ethnic Maori and 70.2 percent identify as ethnically European. ${ }^{14}$ The latest census data, based on the 2018 census, shows that New Zealand has become a very diverse country, mainly due to migration: 27.4 percent of our current population was born overseas. ${ }^{15}$ In the $1950 \mathrm{~s}-1970$ s, most migrants came to New Zealand from Pacific countries but these days Asia is the biggest source of migration. Currently, 15 percent of the population is ethnically Asian, although there is an increasing number of Middle Eastern, Latin American and African migrants with around 1.5 percent of the population drawn from the latter groups combined. ${ }^{16}$ New Zealanders generally tend to embrace diversity and regard it as a good thing. It is worth noting that the population figures cited in this section relate to persons who are "usually resident" in New Zealand, not citizens. ${ }^{17}$

12 This is according to the latest figures released by the government department Statistics New Zealand. See Statistics New Zealand, "New Zealand's population passes 5 million" 18 May 2020 available at: $<$ https://www.stats.govt.nz/news/new-zealands-population-passes-5-million>.

13 Statistics New Zealand, "A history of census-taking in New Zealand" [no date] available at: $<$ http:// archive.stats.govt.nz/Census/2013-census/info-about-the-census/intro-to-nz-census/history/historysummary.aspx\#early>.

14 Statistics New Zealand, "Census summaries - Quick stats about ethnicity for New Zealand (2018 Census) [no date] available at: < https://www.stats.govt.nz/tools/2018-census-place-summaries/newzealand $>$.

15 Statistics New Zealand, "New Zealand's population passes 5 million" 18 May 2020 available at: $<$ https://www.stats.govt.nz/news/new-zealands-population-passes-5-million>.

16 Statistics New Zealand, "2018 Census data allows users to dive deep into New Zealand's diversity" 21 April 2020, available at: <https://www.stats.govt.nz/news/2018-census-data-allows-users-to-divedeep-into-new-zealands-diversity $>$.

17 Note that for the purposes of the five-yearly "Census of Population and Dwellings" (usually referred to simply as the "Census") the term "usually resident" has a specific meaning. The census counts every person who is usually resident in New Zealand at midnight on census night. It is not a legal term and does not relate to immigration status. Anyone who has lived in New Zealand for the past 12 months, or has the intention to live in New Zealand for the next 12 months, would be considered as "usually resident" in New Zealand for the purpose of counting the population: see Statistics New Zealand, "Standard for population terms" [no date] available at: <http://archive.stats.govt.nz/browse_for_stats/ population/standard-pop-terms/glossary-and-references.aspx $>$. 


\section{Population distribution}

With regards to population distribution, Auckland is New Zealand's most populous city, being home to 33.4 percent of the total population (and 50.7 percent of all overseas-born New Zealanders). ${ }^{18}$ Auckland is New Zealand's commercial centre, but the capital is Wellington. Although Auckland is the most populous city $(1,467,800)$, there are also significant populations (in descending order of size) in the cities of Christchurch $(377,200)$, Wellington $(215,400)$, Hamilton $(169,300)$ and Tauranga $(135,000) \cdot{ }^{19}$ As an aside, an interesting statistic is religious affiliation; in 2018 a total of $48.2 \%$ declared that they have no religion, $36.5 \%$ identified as Christian, $2.6 \%$ identified as Hindu, $1.3 \%$ identified as Muslim, $0.2 \%$ as Jewish and $6.7 \%$ objected to answering the question. ${ }^{20}$

\section{Population density}

As for population density, New Zealand has a relatively low density of 18.3 per square kilometre. That low number is due, in part, to the fact that New Zealand consists not just of the main North and South Islands but it also includes a number of largely uninhabited islands such as Stewart Island and the Chatham and Pitt Islands. In fact, 75 percent of New Zealand's population lives in the North Island and one-third lives in Auckland, so population density differs markedly across the country. New Zealand has a mainly urban-based population, with 83.6 percent living in an urban area and 45 percent live in one of the four biggest cities: Auckland, Christchurch, Wellington or Hamilton. ${ }^{21}$ There are many remote rural areas and combined they account for 14 percent of the total population.

\section{Age distribution}

In terms of the total population the overall average age is 37.4 years. As for age distribution overall, 19.6 percent of the total population are in the $0-14$ year age group, 65.5 percent in the 15-64 year age group and 14.9 percent in the 65

18 Ibid.

19 Statistics New Zealand, "Subnational population estimates: At 30 June 2019 (provisional)” 22 October 2010, available at: $<$ https://www.stats.govt.nz/information-releases/subnational-population-estimatesat-30-june-2019-provisional>.

20 Statistics New Zealand, "Census summaries - Quick stats about religion for New Zealand (2018 Census), [no date] available at: <https://www.stats.govt.nz/tools/2018-census-place-summaries/newzealand $>$.

21 Statistics New Zealand, "Subnational population estimates: At 30 June 2019 (provisional)" 22 October 2010, available at: <https://www.stats.govt.nz/information-releases/subnational-population-estimatesat-30-june-2019-provisional>. 
and over group..$^{22}$ However, age distribution varies greatly by region: there is a difference of 20 years for the average age across territorial authorities. For example, in one of the large cities - Hamilton - the average age is 32.3 years whereas in the Thames-Coromandel district the average age is 54.0 years. ${ }^{23}$ Areas with a higher average age tend to have a much higher population in the 65 -and-over age group. The fluctuation across territorial authorities probably reflects the tendency of New Zealanders to "retire to the beach" since the two districts which the highest average age (Thames-Coromandel and Kapiti Coast) are known for their proximity to beautiful and accessible beaches.

\section{Overview of our constitutional arrangements}

New Zealand is a former British colony but it does not have an "independence day" like many other countries. Perhaps the most important "founding document" is the Treaty of Waitangi, which brought about the founding of the state; it was signed on 6 February 1840 between the British Crown and Maori chiefs from the North Island of New Zealand. However, that document has socio-political, rather than legal, force in New Zealand. ${ }^{24}$ It does not have "juridical standing for enforcement in the national courts". ${ }^{25}$ As there were two treaties signed, one in English and one in Maori, with significant differences in translation, the actual meaning of the Treaty of Waitangi has been the focus of significant and continuing academic debate, a summary of which is well beyond the realm of the current article.

New Zealand is one of only three countries in the world that does not have a fully written, codified constitution. ${ }^{26} \mathrm{New}$ Zealand's constitution "is to be found in formal legal documents, in decisions of the courts, and in wellestablished practices (some of which are described as conventions). ${ }^{27}$ New Zealand's constitutional framework is complicated: the sources are many and to understand it fully one needs to consult a long list of old English statutes, New Zealand statutes, the prerogative powers of the Queen and a dazzling

22 Statistics New Zealand, "National population estimates: As at June 2019" available at: $<$ http://archive stats.govt.nz/browse_for_stats/population/estimates_and_projections/NationalPopulationEstimates_ HOTPAt30Jun16.aspx>.

23 Statistics New Zealand, "Estimated population up in all regions - Median age differs by over 20 years across territorial authorities" 22 October 2019 , available at: $<$ https://www.stats.govt.nz/news/estimatedpopulation-up-in-all-regions>.

24 Philip Joseph, Constitutional and Administrative Law in New Zealand ( $4^{\text {th }}$ ed, Thomson Reuters, 2014) at 132 .

25 Ibid.

26 The other two are the UK and Israel.

27 New Zealand Government, Department of the Prime Minister and Cabinet, Cabinet Manual (2017) at https://dpmc.govt.nz/sites/default/files/2017-06/cabinet-manual-2017.pdf, 1. 
array of unenforceable constitutional conventions. One of New Zealand's constitutional experts, Philip Joseph, lists nine separate sources of our constitution: statutes (such as the Constitution Act 1986, the New Zealand Bill of Rights Act 1990 and the Electoral Act 1993), the common law, the royal prerogative, delegated or subordinate legislation, customary international law, law and custom of Parliament, constitutional conventions, and authoritative works of scholars. ${ }^{28}$

One might assume that without a written, codified constitution - as most other countries opt for - the New Zealand Government might be less constrained and more inclined to abuse its power. However, in the current state of national emergency instigated by the COVID-19 pandemic, that has not proven to be the case: as discussed below, the New Zealand Government ${ }^{29}$ took early and firm steps to ensure it would continue to be subjected to Parliamentary oversight, as discussed below in sections 2 and 3 .

\section{Section 2. An overview of the New Zealand Government's response}

The first case of someone in New Zealand with the COVID-19 virus was reported in the media on 28 February 2020, when the Director General of Health advised that an individual who had recently returned from Iran had tested positive. ${ }^{30}$ From 4-7 March there were only three additional cases reported. From 14 March 2020, the Ministry of Health began reporting new cases on its website with details of the age, gender, location and flight details of new cases as they emerged. That website has continued to be updated daily and provides the most recent, official data from the Government on all COVID-19 cases, both current. ${ }^{31}$

The New Zealand Government ("the Government") reacted quickly and firmly to the outbreak of the COVID-19 virus. The New Zealand Prime Minister, Jacinda Ardern, summarized the Government's strategy with the phrase: "we must go hard and we must go early". ${ }^{32}$ The New Zealand response to COVID-19

28 Philip Joseph, "The Laws of New Zealand - Sources of the constitution" (LexisNexis, 2019).

29 The New Zealand Government, the Sixth Labour Government, is currently a Labour Party-New Zealand First Party coalition. The Green Party is not a coalition partner but it has agreed to give support to the Government on confidence and supply issues.

30 Hannah Kronast and Rachel Sadler, "Coronavirus: Timeline of New Zealand's response to COVID-19" NewsHub (20 April 2020) available at: <https://www.newshub.co.nz/home/new-zealand/2020/04/ coronavirus-timeline-of-new-zealand-s-response-to-covid-19.html $>$.

31 See Ministry of Health, "COVID-19 - Current Cases" available at: $<$ https://www.newshub.co.nz/home/ new-zealand/2020/04/coronavirus-timeline-of-new-zealand-s-response-to-covid-19.html> .

32 Bernard Hickey, "We must go hard and we must go early" Newsroom (online, 14 March 2020) available at https://www.newsroom.co.nz/2020/03/14/1083045/we-must-go-hard-and-we-must-go-early>. 
has received praise from various sources. With regards to its early response and detection, Larry Brilliant - an American epidemiologist and international expert on pandemics - said in his opinion, "the island republics of Taiwan, Iceland, and, certainly, New Zealand, would get an A" ${ }^{33}$ Interestingly, he gave Germany and South Korea a "B" and he gave the United Kingdom, and his own country, the United States, an "F" grade for the effectiveness of detection and response. ${ }^{34}$

\section{A travel ban on arrivals from China and other measures}

New Zealand announced on 2 February 2020 that, as of the following day, any travellers from China, or transiting through China, would be refused entry. ${ }^{35}$ That announcement was made on the same day that news broke of the first person dying of COVID-19 outside China, when a man from Wuhan died in the Philippines. ${ }^{36}$ That response, to immediately ban all travellers from China, was integral to New Zealand's early success in reducing the number of cases entering the country. Looking back, it seems obvious that it was the right decision, but it was controversial at the time, especially given the strong financial incentives to keep our borders open to Chinese travellers. In May, the Government proactively released previously confidential papers and amongst them is an Aide Memoire from the Ministry of Health to the PM which states that New Zealand usually receives 3,500 passengers a day that list their country of origin as China. In addition, between five and nine flights come from China to New Zealand each day as well as a further two flights from Hong Kong and one from Taipei. ${ }^{37}$ The Government's sudden travel ban on all Chinese travellers was certainly not supported by everyone (a fact that is easy to forget, now that we have witnessed the death toll in other countries). The Chinese government, through its consul in New Zealand,

33 TED2020, "Larry Brilliant: A global pandemic calls for global solutions" TED2020 (online, recorded 22 April 2020) available at: $<$ https://www.ted.com/talks/larry_brilliant_a_global_pandemic_calls_for_ global_solutions $>$, especially at $2 \mathrm{~min} 55 \mathrm{sec}$ of the talk. Note that he referred to "the island republics of Taiwan, Iceland, and certainly New Zealand" as nations deserving of an "A" grade for their response, but New Zealand is not a republic, it is a constitutional monarchy.

34 Ibid at $3 \mathrm{~min}$ of the talk.

35 Radio New Zealand, "NZ to close doors on foreign travellers from China" $R N Z$ (online ed, 2 February 2020) available at: < https://www.rnz.co.nz/news/national/408675/nz-to-close-doors-on-foreigntravellers-from-china>.

36 Ibid.

37 Ministry of Health, "Aide Memoire: Health advice on appropriate border measures for novel coronavirus from the Ministry of Health to the Rt Hon Prime Minister Jacinda Arden" 2 February 2020, released proactively by the New Zealand Government on 8 May 2020, available at: $<$ https://covid19. govt.nz/assets/resources/proactive-release/Health-advice-on-appropriate-border-measures-for-novelcoronavirus.pdf $\$$. 
openly criticized the travel ban, with the consul general telling the media he was very "disappointed" and indicating that this decision would have a negative effect on relations between China and New Zealand. ${ }^{38}$ The decision was also a difficult one to accept for many of New Zealand's key sectors, especially education and tourism. Since New Zealand universities receive significant income from Chinese students, university leaders within New Zealand criticized the Government for putting in place the Chinese travel ban, saying it would cost thousands of jobs ${ }^{39}$ and would probably cost our universities and polytechs around \$NZ100 million in revenue..$^{40}$ The tourism sector also voiced its concerns, claiming it would similarly cost the tourism sector around \$NZ100 million in lost revenue since our tourism sector has relied heavily on Chinese visitors for many years. ${ }^{41}$

The New Zealand Government ignored the internal and external pressure to ease the travel ban and maintained its "go hard and go early approach" in the face of both internal and external criticism. Its response was ramped up substantially at a special Cabinet meeting held on Saturday $14 \mathrm{March}^{42}$ when the Government announced four key developments: all arrivals to New Zealand, regardless of origin, would henceforth have to go into isolation for 14 days, all cruise ship arrivals would be halted until at least 30 June, no one would be allowed to travel to one of the Pacific islands if they were exhibiting flu symptoms or if they had returned recently from a non-Pacific island and there would be an immediate cancellation of large events and gatherings. Prime Minister Arden spoke of the need to "flatten the curve" and prevent our health system from being overwhelmed..$^{43}$ On 19 March the New Zealand Prime Minister announced that the borders would close to all travelers regardless of origin - except New Zealand citizens and permanent

38 Radio New Zealand, "Chinese consul general criticizes decision to bar travellers from China over coronavirus concerns" $R N Z$ (online ed, 3 February 2020) available at: $<$ https://www.rnz.co.nz/ news/national/408720/chinese-consul-general-criticises-decision-to-bar-travellers-from-china-overcoronavirus-concerns $>$.

39 Hamish Rutherford, "Universities warned travel ban was doing 'incalculable damage' to China relationship" NZ Herald (online ed, 14 March 2020) available at: <https://www.nzherald.co.nz/ business/news/article.cfm?c_id=3\&objectid=12316514>.

40 Radio New Zealand, "How coronavirus could cost our universities and polytechs $\$ 100$ million" $R N Z$ (26 February 2020) available at: < https://www.rnz.co.nz/news/national/409632/how-coronaviruscould-cost-our-universities-and-polytechs- $100 \mathrm{~m}>$.

41 Amanda Cropp, "Close to $\$ 100$ million hole in tourism earnings from Chinese travel ban" Stuff (online, 3 February 2020) available at: <https://www.stuff.co.nz/business/119226865/close-to-100-millionhole-in-tourism-earnings-from-chinese-travel-ban>.

42 Cabinet meetings are usually held on Mondays.

43 Hickey, "We must go hard and we must go early", supra n 10. 
residents - from midnight that day. ${ }^{44}$ Then on 23 March she announced that the country was going into lockdown.

It is submitted that the Government's swift and strong response was both courageous and bold: the Government demonstrated that it was not afraid to offend powerful trading partners, such as China, in order to secure New Zealanders' health, nor was it intimidated by public calls from the tertiary education and tourism sectors that border closures and travel bans would cause losses measured in the hundreds of millions of dollars. It was also a humane response, in the sense that both New Zealand citizens and permanent residents (and their partners and children) were still allowed to return home throughout the pandemic response, unlike some other countries which completely closed their borders and ceased all international flights. That decision was made by the Government, even though some health professionals at the time, including the Ministry of Health, advocated strongly for a total closure of the border-including to New Zealand citizens and permanent residents. ${ }^{45}$ This decision was, in retrospect, the right one and New Zealand managed to overcome the crisis whilst also allowing New Zealand citizens and permanent residents to come home. Nevertheless, holders of inter alia temporary work visas, student visas and visitors visas, were essentially locked-out of New Zealand for the time-being. Some of those people have voiced their frustration at not being able to enter New Zealand despite holding valid visas. ${ }^{46}$ It is submitted that with the benefit of hindsight, the Government took an approach which was proactive, humane and balanced.

\section{The 4-tiered Alert Level System}

A key element of the Government's response was its quick creation of a 4-level alert system to make it clearer to New Zealanders what activities would be permitted at each level. The alert levels were separate from the state of emergency, discussed below. These new alert levels were explained at a

44 Radio New Zealand "New Zealand to close its borders to anyone not a citizen or permanent resident" RNZ (online ed, 19 March 2020) available at: <https://www.rnz.co.nz/news/national/412162/nz-toclose-its-borders-to-anyone-not-a-citizen-or-permanent-resident-pm-confirms $>$.

45 Collette Devlin, "Coronavirus: Winston Peters says Health Ministry wanted to close borders to Kiwis" Stuff (online ed, 29 April 2020) available at: <https://www.stuff.co.nz/national/health/ coronavirus/121330996/coronavirus-winston-peters-says-health-ministry-wanted-to-close-borders-tokiwis>.

46 Megan Harvey, “COVID-19 Coronavirus: Stranded work visa holders' heartbreaking plea to return to New Zealand" NZ Herald (online ed, 21 May 2020) available at: $<$ https://www.nzherald.co.nz/nz/news/ article.cfm?c_id=1\&objectid=12333855>. 
press briefing on 21 March. In summary they may be explained as follows: ${ }^{47}$

- Alert Level 1: This was when COVID-19 was present in New Zealand, but contained. This phase was about preparation including the introduction of border measures, contact tracing and cancelling large gatherings. This level was announced after New Zealand had passed beyond it.

- Alert Level 2: This was when COVID-19 was contained but the risks were growing as the number of cases increased. At this stage, people were encouraged to reduce contact with others and border measures would be further tightened. All non-essential travel, such as university staff travelling to conferences or bringing researchers to New Zealand, was cancelled. All large gatherings (initially of 500 people, then this was reduced quickly to 100) were prohibited. ${ }^{48}$ The existence of this level was also announced after New Zealand had passed beyond it.

- Alert Level 3: This was where COVID-19 became increasingly difficult to contain. Public venues and non-essential businesses were advised that they would need to close. Universities, for example, told their staff to prepare to work from home- at salert level 4 faculty would no longer have access to their university offices. Schools were advised that they would have to close to all students except those whose parents worked in essential services (i.e. only children whose parents were doctors, nurses, police officers etc. were allowed to attend school).

- Alert Level 4: This was where COVID-19 could be shown to have spread by community transmission and the daily increase in cases was not just attributed to overseas arrivals (i.e. from New Zealanders coming home with the virus). Only essential services such as hospitals, medical clinics, supermarkets and petrol stations would be permitted to stay open (but

47 Stuff "Coronavirus alert system: What you need to know" Stuff (online, 21 March 2020) available at: $<$ https://www.stuff.co.nz/national/health/coronavirus/120468173/coronavirus-alert-system-what-youneed-to-know $>$. Many of the items listed above for these alert levels were not announced on 21 March 2020 but have become generally well-known as the Government's daily press briefings have helped to explain and flesh out what each level means in practical terms. It has become clear, since their implementation, that permitted activities might alter as restrictions ease on the way down through the alert levels.

48 A blanket ban on gatherings of more than 500 people was announced on 15 March and then after four days, on 19 March 2020, a ban on gatherings of more than 100 people was announced: see Jason Walls, "Coronavirus: Gatherings of more than 100 people banned to stop spread" NZ Herald (19 March 2020) available at: <https://www.nzherald.co.nz/nz/news/article.cfm?c_id=1\&objectid=12318220>. The bans on gatherings did not apply to schools, universities or any other educational institutions, which continued to hold classes and lectures as usual at that point. 
with new protocols for operations, such as having to queue in your car at a medical centre; having restrictions on entering supermarkets). Workers who could not work from home were essentially placed on a "staycation", meaning, they had to stay at home in their "bubble".

New Zealand entered Alert Level 3 via the Prime Minister's announcement at $1.30 \mathrm{pm}$ on Monday 23 March. It was also announced at that time that just two days later, at midnight on 25 March, New Zealand would enter Alert Level 4 (i.e. a near total lockdown). Since waking up on 26 March, New Zealand was at Alert Level 4 but no curfew was ever imposed. All schools and universities were completely closed at Alert Level 4 (with university academics conducting classes online from their homes), all food outlets including cafes, restaurants and fast-food businesses were also completely closed. In fact, all businesses across New Zealand - except "essential services" such as hospitals, supermarkets, farmers, food manufacturers, medical equipment manufacturers and petrol stations - were forced to close their doors and send their workers home. The whole country was placed in isolation.

The Government instructed everyone to stay at the address that they were located at when we entered Alert Level 4 at midnight on 25 March - and to stay with the same "bubble" of family members that they were with at that crucial moment for at least 4 weeks. Everyone was allowed to leave their homes to buy essential goods and to exercise, as long as they did that locally, close to their home.

These alert levels were an integral part of the Government's response and they were initially created very quickly; when New Zealand started to go back down from Alert Level 4 to Level 3 (on 28 April) then Alert Level 2 (announced on 11 May; took effect on 14 May) and eventually Alert Level 1 sometime in the future (but at least four weeks from the time of writing), the permitted activities at each level were further refined. In other words, some differences applied on the "way down" through the levels as compared to on the "way up" given that there was more time to consider what activities would be permitted. For example, when New Zealand went down from Alert Level 4 to Alert Level 3 (at 11.59pm on Monday 27 April) schools were allowed to reopen for students up to and including Year 10, but only if there is no one at home to look after them; all other students had to initially continue with home-schooling. If students did have to return to school at Alert Level 3 , they were kept in small "bubbles" and had to spend all their time at school interacting only with students and teachers in their bubble.

The Government was obviously involved in a balancing act when moving 
from Alert Level 4 to Alert Level 3: trying to reopen schools and move from home-schooling back to face-to-face schooling was desirable as soon as possible but at the same time there was an acknowledgment that schools could be seriously affected if just one case of COVID-19 made its way into the school environment. All "essential" and "safe" businesses were permitted to re-open at Alert Level 3, as long as there was no face-to-face contact with customers, thus, fast-food outlets such as McDonalds and Burger King could re-open to drive-through customers only.

At the time of writing (Monday 25 May 2020), New Zealand is at Alert Level 2 and has been so since Thursday 14 May. As of that day, all schools were permitted to reopen but generally speaking most schools only allowed their teachers back that day, to give them a couple of days (Thursday and Friday) to prepare for the return of their students. Subsequently, all schools opened their doors to all students, across the country, on Monday 19 May 2020. Most students in New Zealand are now back in school. Universities and polytechnics are also permitted to allow students on campus but the current threshold of gatherings being limited to 10 students means that, for all intents and purposes, online teaching and learning is continuing for most tertiary institutions. The threshold for gatherings will increase from 10 people to 100 people at noon on Friday 29 May 2020 and a reduction to level 1 will probably take place in four weeks time. ${ }^{49}$

The announcement of a return to Alert Level 2 on 11 May, and its implementation on 14 May, means, practically speaking, that life has now almost returned to normal. Cafes, restaurants, shops, libraries, gyms, playgrounds, schools, early childhood education centres and workplaces are all open, although some restrictions are in place. For instance, when entering cafes and retail shops, customers are asked to observe a 2-metre social distancing rule and customers are asked to either sign-in with their contact details or download the COVID-19 tracing app on their phone and register their attendance in a venue. At the time of writing, 365,000 people have downloaded the app and can scan a unique QR code when they arrive at a new public location such as a café or retail store. ${ }^{50}$ These measures have been put in place to make contact tracing easier, if there is a second-wave of the virus.

49 Collette Devlin, "Coronavirus: Prime Minister Jacinda Ardern lays out road to level 1, increases crowd limit to 100" Stuff 25 May 2020, available at: <https://www.stuff.co.nz/national/health/ coronavirus/121618998/coronavirus-prime-minister-jacinda-ardern-lays-out-road-to-level-1-increasescrowd-limits-to-100>.

50 [no stated author] "COVID-19 Coronavirus: Cabinet to decide today whether to increase gathering size; 2 bars closed" NZ Herald (online ed, 25 May 2020) available at: $<$ https://www.nzherald.co.nz/nz/ news/article.cfm?c_id=1\&objectid=12334341>. 


\section{Analysing the effectiveness of the New Zealand Government's response}

At the time of writing, the statistics are very pleasing and (at least at the present time) point to New Zealand being one of the few countries to have emerged from the COVID-19 pandemic with minimal loss of life.

As of today, 25 May 2020, the key statistics in New Zealand are as follows: there are only 27 active cases of COVID-19. There has only been one new COVID-19 case in the past week and it was linked to an existing cluster of cases from an Auckland rest-home. Prior to that, there were three days with zero new cases per day. Overall, the total number of confirmed cases is 1,154 and the total of confirmed plus probable cases is 1,504. There is only one person in a New Zealand hospital being treated for COVID-19 and there are none in intensive-care units. There have been 21 deaths in total due to COVID-19, but all except one of those deaths have involved patients aged 70 or over, most with underlying health conditions, many of them from aged-care residential facilities. ${ }^{51}$ New Zealand has succeeded in not only "flattening the curve", with virtually day-on-day reductions, but it has almost completely eradicated COVID-19. This demonstrates, in this author's opinion, that the New Zealand Government's response has been extremely effective. On this day-25 May 2020 - around the world, the comparative numbers are frightening: New Zealand has 21 deaths whereas the US has 94,024 deaths; the UK has 36,793 deaths; Brazil has recorded 22,746 deaths. Even countries with similar populations to New Zealand (around 4-5 million people) have experienced a much greater loss of life. ${ }^{52}$ For example, Kuwait has recorded 21,302 total cases as of 24 May and 156 deaths overall $;^{53}$ Ireland has recorded 24, 639 total cases and 1,608 deaths. ${ }^{54}$ Norway has recorded 8,322 cases and 235 deaths. ${ }^{55}$ Comparatively speaking, New Zealand has emerged almost unscathed which tends to support the finding that the New Zealand Government's response has been very effective.

51 Ten deaths (as of 25 May) were elderly residents of Rosewood Resthome in Christchurch, most of home were in their $80 \mathrm{~s}$ or $90 \mathrm{~s}$, and only one death was of a man in his $60 \mathrm{~s}$. Almost every death to date involved a patient at an elderly care facility. As at the time of writing, there were 21 total deaths in New Zealand from COVID-19: see Ministry of Health, "COVID-19 - Current Cases" available at: <https:// www.health.govt.nz/our-work/diseases-and-conditions/covid-19-novel-coronavirus/covid-19-currentsituation/covid-19-current-cases $>$.

52 The populations of Kuwait (4.2 million), New Zealand (5 million) and Norway (5.4 million) are roughly similar and are used as examples to roughly compare a few countries on the basis of total population.

53 Kuwait Times, 24 May 2020, available at: <https://news.kuwaittimes.net/website/>.

54 The Irish Sun, 24 May 2020, available at: <https://www.thesun.ie/news/5372444/communitytransmission-59-per-cent-covid-19-cases/>.

55 David Nikel, "Coronavirus in Norway: The Latest News on the COVID-19 outbreak" (online, 22 May 2020) available at: <https://www.lifeinnorway.net/coronavirus-in-norway/>. 
It is impossible to know whether this level of success will continue once the country moves from Alert Level 2 to Alert Level 1 and once it re-opens its borders to all travelers. Regardless of what the future holds, it is submitted that the current data proves the effectiveness of the Government's response. Since a picture is worth a thousand words, four key graphs are presented below which support that perspective.

Figure 1 shows the slowing rate of infection as of 25 May 2020. The flattening of the line on the graph throughout April and May demonstrates that New Zealand has succeeded in bringing the virus completely under control and almost completely eradicating it as of 25 May 2020.

Figure 1: The epidemic curve of total confirmed and probable cases of COVID-19 in New Zealand as of 25 May 2020

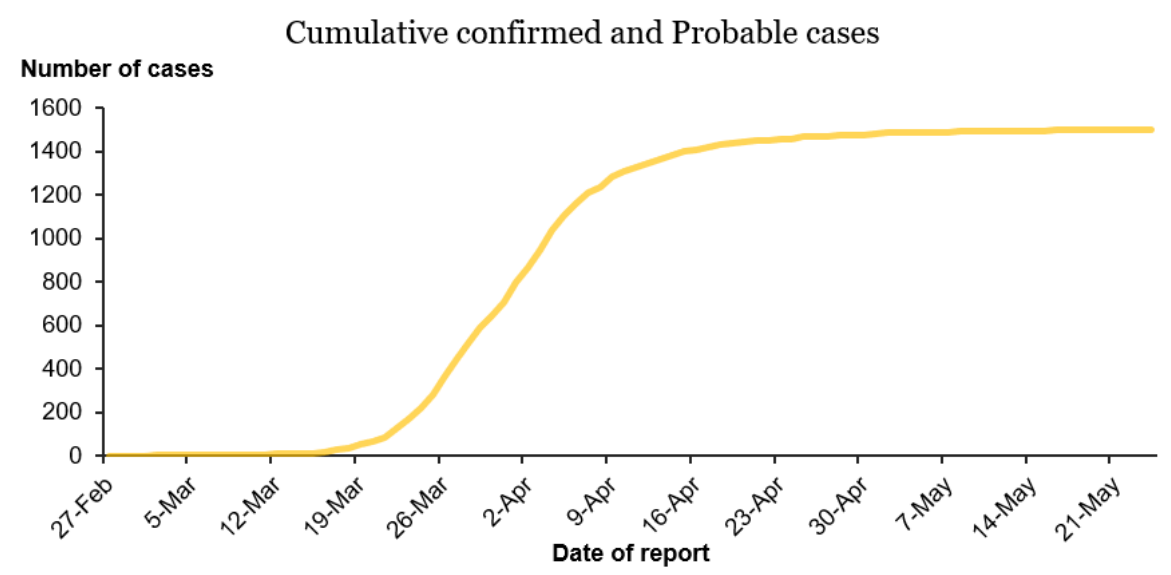

56 Ministry of Health, "COVID-19 Current Cases" 25 May 2020, available at: $<$ https://www.health.govt. $\mathrm{nz} /$ our-work/diseases-and-conditions/covid-19-novel-coronavirus/covid-19-current-situation/covid19-current-cases>. 
Figure 2: The daily confirmed and probable cases, current to 25 May 2020.57

Daily confirmed and probable cases

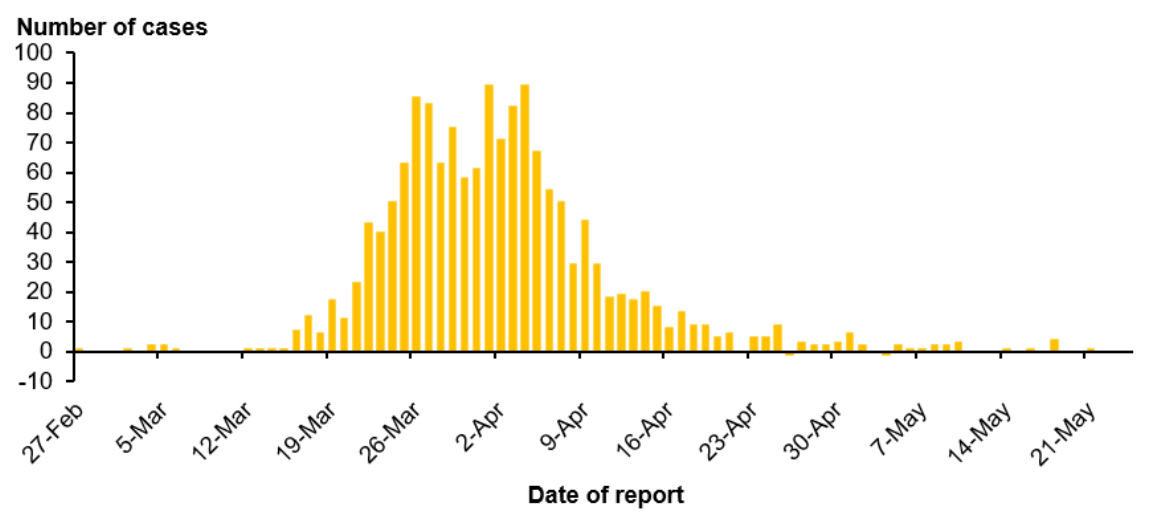

The above graph shows the number of new cases reported each day. It is evident from Figure 2 that the number of new cases peaked between 26 March and 5 April. Throughout April the number of new cases slowed as the Government's Alert Level 4 lockdown took effect. The month of May shows several days with zero new cases and there is no day in May with more than 5 new cases.

Figure 3 shows the geographical spread of the cases and this is very interesting because it shows something expected and something unexpected. As expected, it shows that the most populous and densely populated parts of the country were hit hard (Auckland and Christchurch) but, perhaps unexpectedly, population density did not automatically translate into high numbers of cases, and low population density did not guarantee escape from COVID-19.

57 Ibid 
Figure 3: The geographical spread of the total number of confirmed and probably cases $(1,504)$ as of 25 May $2020 .{ }^{58}$

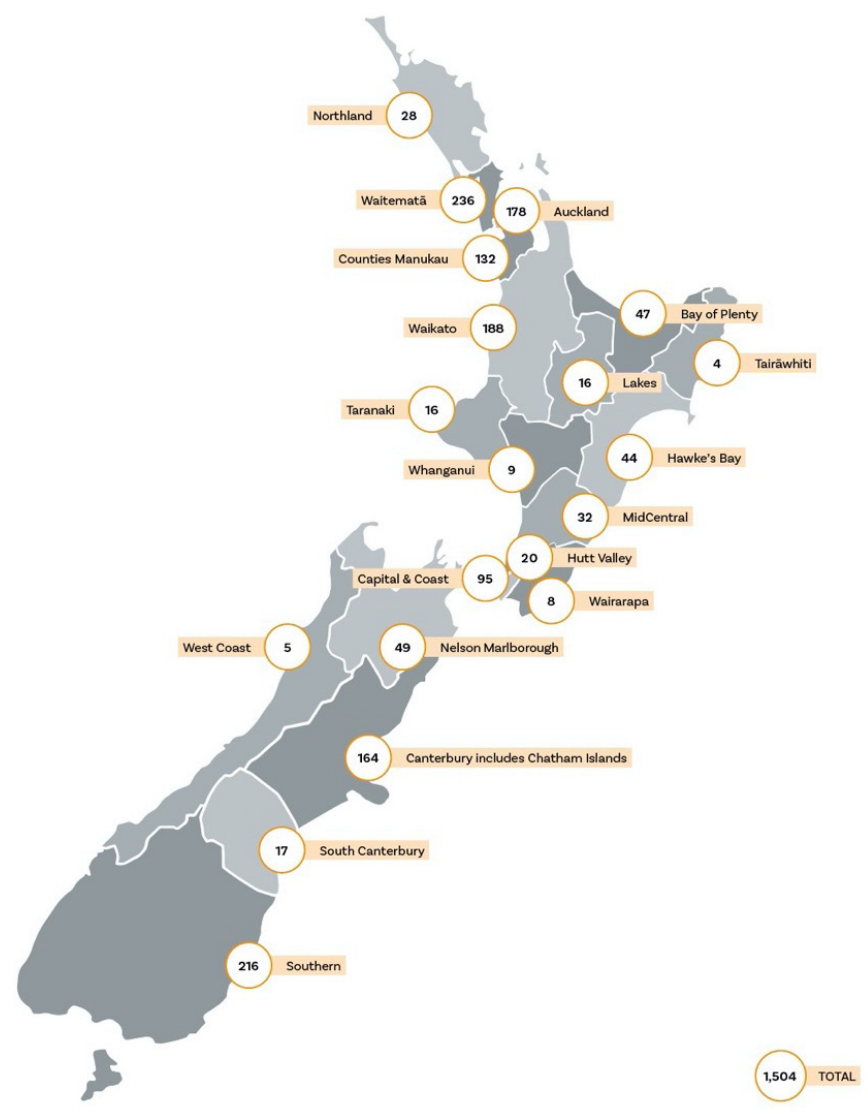

The "Southern" region, as depicted on Figure 3, is not densely populated, comparatively speaking, yet it recorded a disproportionate 216 of the 1,504 total cases. That was largely the result of two clusters. One cluster was traced to a wedding in Bluff. Bluff is a very small town (population 1,767) located at the very bottom of the South Island of New Zealand. The Bluff wedding accounted for 98 cases, 95 of which have now recovered. ${ }^{59}$ The original source was overseas visitors coming to attend the wedding which was held in Invercargill, with the reception of 65 guests held at Bluff's Oyster Cove

58 Ibid.

59 Ministry of Health, "COVID-19: Significant Clusters" 25 May 2020, available at: $<$ https://www.health govt.nz/our-work/diseases-and-conditions/covid-19-novel-coronavirus/covid-19-current-situation/ covid-19-current-cases/covid-19-significant-clusters $>$. 
Restaurant.$^{60}$ The other significant cluster in the Southern region was traced to an international conference, the World Hereford Conference, held in Queenstown, which accounted for 39 cases of COVID-19, all of which have now recovered ${ }^{61}$ Again, the source of infection was overseas visitors coming to attend the conference. These findings are interesting because although it might be assumed that population density is a guarantee for a high number of cases, and vice versa for areas of low populations density, the New Zealand experience does not necessarily bear that out. A single case of COVID-19 can wreak havoc even in a sparsely populated area.

The fourth and final graph, Figure 4, shows the correlation between age and cases of COVID-19; it breaks down the total number of confirmed and probably cases by age. It also shows the number of deaths in each age-group: no one under the age of 60 years old died. In the 60-69 age group there were three deaths; in the 70-79 age group there were seven deaths; in the 80-89 age group there were also seven deaths and in the 90 and above age group there were four deaths. ${ }^{62}$

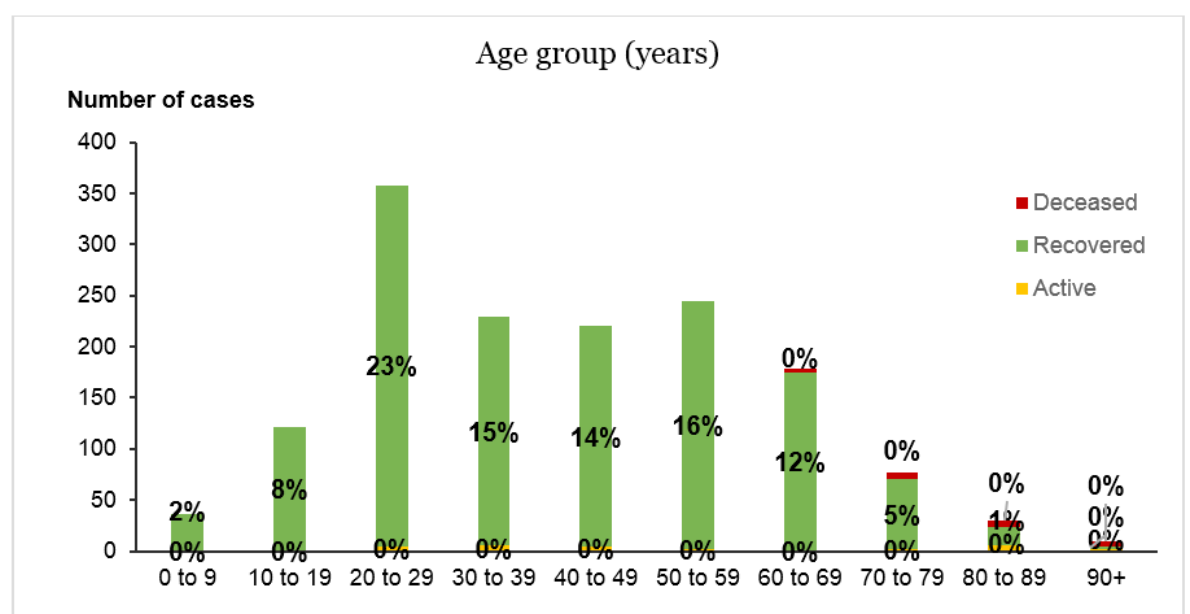

It is submitted that the above four graphs show a coherent story of the New Zealand Government's success at controlling and then virtually eradicating the COVID-19 coronavirus.

60 Evan Harding, "Coronavirus: How a wedding reception in Bluff caused New Zealand's biggest COVID-19 cluster" Stuff (online ed, 10 April 2020) available at: <https://www.stuff.co.nz/national/ health/coronavirus/120863226/coronavirus-bluff-wedding-cluster-now-the-largest-in-new-zealand>. 61 Ibid.

62 Ministry of Health, "COVID-19: Current Cases" 25 May 2020, available at: <https://www.health.govt. nz/our-work/diseases-and-conditions/covid-19-novel-coronavirus/covid-19-current-situation/covid19-current-cases>. 


\section{Economic impact and response of COVID-19 and the lockdown}

The health response and the economic response are integrally connected. As the Minister of Health said in the House of Representatives on 6 May 2020, "it's been widely acknowledged that the public health response is indeed the best economic response." ${ }^{63}$ Despite the success in controlling the spread of the virus, the nationwide lockdown has had, and is continuing to have, a dire effect on the New Zealand economy, leading to the need for a massive bail-out package to support businesses and individuals. At the time of writing, \$NZ9.9 billion has been paid by the Government to employers to pass on to their employees as wage subsidies; unemployment is expected to rise throughout the year as some businesses fold, despite the Government's monetary support. The Government has encouraged employers to keep their staff paid and employed, even though they are at home and may have no work to do. To that end, every worker, whether self-employed or employed in the public or private sector, has had access to a weekly payment of \$NZ585.00 if their earnings were affected by COVID-19. A range of other fiscal support measures were also introduced, including the Government preventing any rent increases or tenancy terminations for six months, even for unpaid rend (for those in the rental market) and the introduction of "mortgage holidays" for six months (for those who own their home secured by a bank mortgage). Despite the Government's efforts at supporting employees and employers alike, the long-term financial implications are likely to be negative for years to come. The International Monetary Fund, which is referring to this event as the "Great Lockdown", expects that the New Zealand economy will shrink by $7.2 \%$ this year before growing at $5.9 \%$ next year, and the global economy is expected to contract by about $3 \%$ in 2020 , a sharper fall than that experienced during the Global Financial Crisis. ${ }^{64}$ The following section of this paper discusses the legislative basis for the lockdown and the way in which the New Zealand Government has utilized, but not abused, its statutory powers to manage the crisis.

\section{Section 3. Declaration of a State of National Emergency \& its Statutory Basis}

A "State of National Emergency" applying to the whole of New Zealand

63 Minister of Health Hon Dr David Clark, "Ministerial Statements", Hansard 13 May 2020, available at: $<$ https://www.parliament.nz/en/pb/hansard-debates/rhr/combined/HansD_20200506_20200506>.

64 IMF, "World Economic Outlook 2020: Chapter 1-The Great Lockdown" (online, April 2020) available at: $<$ https://www.imf.org/en/Publications/WEO/Issues/2020/04/14/weo-april-2020>. 
was declared at $12.21 \mathrm{pm}$ on 25 March $2020 .{ }^{65}$ This was the first time in New Zealand's history that a state of emergency was announced which applied to the whole country including Stewart Island, the Chatham Islands and other offshore islands. The only previous state of emergency was declared in response to the 2011 Christchurch earthquake and was limited to the locally affected area. A state of emergency lasts for seven days unless extended. The state of emergency that was declared on 25 March 2020 was subsequently extended six times and it finally ended at $12.21 \mathrm{pm}$ on Wednesday 13 May $2020 .{ }^{66}$ The State of National Emergency was initially declared by the Minister of Civil Defence, pursuant to section 66 of the Civil Defence Emergency Management Act $2002^{67}$ and extended every seven days pursuant to section 71 of the same Act.

The Prime Minister made a Ministerial Statement to the House of Representatives, under Standing Order 347, on 25 March 2020. In it, she explained the reason for the declaration of a State of National Emergency: ${ }^{68}$

\section{The Minister of Civil Defence took this step because of the unprecedented nature of this global pandemic, and because he considered the response required to combat COVID-19 is of such a degree that it will be beyond the capacity of local Civil Defence Emergency Management Groups to respond on their own. The pandemic also requires a significant and coordinated response by and across central and local government.}

The Civil Defence Emergency Management Act 2002 (pursuant to which the State of National Emergency was declared) provides a comprehensive legislative framework to respond to the various threats that New Zealanders have to live with, such as earthquakes, floods, volcanic eruptions, hurricanes and, as it turns out on this occasion, pandemics. This statute has several purposes: to promote the sustainable management of hazards; to provide for planning and preparation for emergencies, and for response and recovery; to require local authorities to coordinate planning and activities; to provide

65 Civil Defence - National Emergency Management Agency, "State of National Emergency Due to COVID-19" 21 March 2020, available at: <https://www.civildefence.govt.nz>.

66 Zane Small, "COVID-19: State of Emergency Ends in New Zealand making way for 'transition' period" NewsHub (online ed, 13 May 2020) available at: <https://www.newshub.co.nz/home/politics/2020/05/ covid-19-state-of-emergency-ends-in-new-zealand-making-way-for-transition-period.html>.

67 Section 66 Civil Defence Emergency Management Act 2002, available at: < http://www.legislation.govt. nz/act/public/2002/0033/51.0/DLM150776.html>.

68 New Zealand Government, "Prime Minister's Statement on State of National Emergency and Epidemic Notice - Right Honourable Jacinda Arden" Beehive.govt.nz (online, 25 March 2020) available at: $<\quad$ https://www.beehive.govt.nz/speech/prime-minister's-statement-state-national-emergency-andepidemic-notice>. 
a basis for the integration of national and local civil defence emergency management; and to encourage coordination across a wide range of agencies. ${ }^{69}$ There are wide-ranging powers under the Act, and a comprehensive analysis of this Act is beyond the scope of this paper. Suffice to say that the powers in relation to a civil defence emergency are set out in Part 5 of the Civil Defence Emergency Management Act 2002. For example, section 85 provides for Civil Defence Emergency Management Groups to have the power to, inter alia, carry out works, clear roads, and other public spaces, and remove or otherwise make safe any dangerous structures or materials $;^{70}$ provide for the rescue of endangered persons $;{ }^{71}$ set up first-aid posts $;{ }^{72}$ provide for emergency food, shelter or clothing $;^{73}$ provide for the conservation or supply of food, fuel or other essential supplies; ${ }^{74}$ prohibit or regulate land, water and air traffic $;{ }^{75}$ undertake emergency measures for the disposal of dead animals or persons; $;^{76}$ disseminate information and advice to the public; $;^{77}$ enter into arrangements including employment arrangements with any person to carry out civil defence emergency management; ${ }^{78}$ and provide equipment, accommodation and facilities for the exercise of any of the aforementioned powers. ${ }^{79}$

In practical terms, invoking the provisions of the Civil Defence Emergency Management Act 2002 enabled the Government to take such important measures as requisitioning carparks for the purposes of COVID-19 testing, use council land for the purposes of creating temporary accommodation and close some roads.

This legislation gives real power to civil defence officials, and the Police, to manage a crisis in accordance with a civil defence management plan. The law has "teeth" in the sense that it creates a criminal offence for failure to comply with any aspect of a civil defence management plan. ${ }^{80}$ Such an offence carries a maximum penalty of imprisonment up to three months or a fine of up to

\footnotetext{
69 Section 3 Civil Defence Emergency Management Act 2002.

70 Ibid, section 85(1)(a).

71 Ibid, section 85(1)(b).

72 Ibid, section $85(1)(\mathrm{c})$.

73 Ibid, section $85(1)(d)$.

74 Ibid, section 85(1) (e).

75 Ibid, section 85(1)(f).

76 Ibid, section $85(1)(\mathrm{g})$.

77 Ibid, section $85(1)(\mathrm{h})$.

78 Ibid, section 85(1)(i).

79 Ibid, section 85(1)(j).

80 Section 95 Civil Defence Emergency Management Act 2002: “A person commits an offence who intentionally fails to comply with a requirement in a civil defence emergency management plan".
} 
$\$ N Z 5,000$, or both — if the offender is an individual — or a maximum fine of $\$ \mathrm{NZ50,000}$ if the offender is a body corporate. ${ }^{81}$

The Government has used its powers under the Civil Defence Management Act 2002, it is submitted, with a large dose of common sense and discretion, which aligns with government's overall approach of combining education of the public with prosecution when necessary. For example, over the Easter Holiday period - a period when families traditionally head away to the beach for a few days - no one was supposed to leave their homes except for essential workers and people needing to go to the supermarket or the doctor. Under the Act, the police set up about 500 police checkpoints across the country, to stop drivers and ask them where they were going: this is very unusual in New Zealand, where checkpoints are used for breath alcohol monitoring but seldom on major roadways. The Police reported that over the Easter Holiday period, ${ }^{82} 662$ people were spoken to at those check-points and out of those, there would be 64 prosecutions. ${ }^{83}$

The rest of the people who were stopped were either permitted to continue or given a warning. ${ }^{84}$ This was an example of rather heavy enforcement, comparatively speaking, because up until Easter, the Police had been pursing more of an "education and encouragement" approach. ${ }^{85}$ But due to the fact that the lock-down had been in place since 25 March, the Police felt it was time to make sure that New Zealanders were obeying the lock-down rules.

New Zealand managed to secure a high level of obedience to the Alert Level 4 lockdown rules, in part through education and encouragement, and in part through punishment, when necessary, for those who flagrantly refused to follow the civil defence management plan. This approach aligns fairly well with New Zealanders' general attitude, which is that they like to see people given a "fair go" and do not like to see their Police force taking an unduly harsh approach, even in an emergency.

81 Section 105 Civil Defence Emergency Management Act 2002.

82 The Easter holiday period was Friday 10 April until Tuesday 14 April 2020.

83 Radio New Zealand, “COVID-19 lockdown: 64 prosecutions for breaches over Easter” RNZ (online ed, 13 April 2020) available at: <https://www.rnz.co.nz/news/national/414137/covid-19-lockdown-64prosecutions-for-breaches-over-easter $>$.

84 Ibid.

85 Ibid. At the beginning of the Alert Level 4 lockdown, the Police were noticing a lot of breaches, but their general approach was one of educating and warning: see Radio New Zealand, "New Zealand lockdown: Rule breakers warned by police on first night of alert level 4" $R N Z$ (online ed, 26 March 2020) available at: <https://www.rnz.co.nz/news/national/412634/new-zealand-lockdown-rule-breakers-warned-bypolice-on-first-night-of-alert-level-4>. 
It is submitted that this response is sensible and it is probably more effective than harsh penalties - such as threatening "deportation for expatriates who violate the curfew" which has been reported as a genuine threat issued against foreigners in some countries, including Kuwait ${ }^{86}$ and the United Arab Emirates. $^{87}$

The concept that a person (the abovementioned threat applies only to an expatriate, not a citizen, which raises questions about why different offenders would receive different penalties for committing the same offence) could be deported from their country of residence for violating a curfew/lockdown order seems unnecessarily harsh. Such a harsh penalty is not available under the New Zealand legislation, and rightly so ${ }^{88}$ It is argued by this author that in a state of emergency, when the Government wants everyone to work together and cooperatively to achieve a national goal (i.e. the reduction of social contact to contain the spread of COVID-19), it seems that it is better to encourage everyone to help in the national effort, and to educate them as to how they can help, rather than threatening some members of the public with draconian punishments such as deportation: the former approach, rather than the latter, has worked well for New Zealand.

It is interesting to note here that psychologists have studied the effect of contagions on people's behavior and there is research which suggests that "fear of disease can influence people's attitudes to immigration". ${ }^{89}$ In research conducted prior to COVID-19 it has been shown that we have heightened distrust of people from other cultures and backgrounds when we feel vulnerable to contagions..$^{90}$ This might help to explain some reports of antiimmigration and anti-immigrant sentiment, expressed overtly in the media, with an apparently heightened opposition to foreigners, during the COVID-19

86 For example, see Kuwait: Arab News "Kuwait to deport expatriates who violate curfew hours" Arab News (online ed, 23 April 2020) available at: < https://arab.news/2zqve>.

87 Anjana Sankar, "UAE combats COVID-19: Residents face deportation for breaking rules" Khaleej Times (online ed, 12 April 2020) available at: <https://www.khaleejtimes.com/coronavirus-pandemic/ uae-residents-face-deportation-for-breaking-covid-19-rules-->.

88 The maximum penalty under s 105 Civil Defence Emergency Management Act 2002 is a \$NZ5,000 fine or up to 3 months in jail.

89 David Robson, "The threat of contagion can twist our psychological reactions to ordinary interactions, leading us to behave in unexpected ways" $B B C$ (online, 2 April 2020) available at: $<$ https://www.bbc. com/future/article/20200401-covid-19-how-fear-of-coronavirus-is-changing-our-psychology>.

90 Lene Aarøe, Michael Bang Petersen and Kevin Arceneaux "The Behavioural Immune System Shapes Political Intuitions: Why and How Individual Differences in Disgust Sensitivity Underlie Opposition to Immigration" American Political Science Review (2017) 111 (2) at 277, available at: <https://www. sciencespo.fr/cevipof/sites/sciencespo.fr.cevipof/files/Aaroe $\% 202017 \% 20$ The $\% 20$ behavioral $\% 20$ immune $\% 20$ system $\% 20$ shapes\%20political\%20intuitions-1.pdf> . 
pandemic. ${ }^{91}$ An examination of this phenomena is beyond the scope of this paper, but it is probably an area that psychologists will explore further as the dust settles and when there is more time to reflect on the connection between a pandemic and the psychological reaction to foreigners/expatriates and immigration.

The international media has also commented on the means used by the New Zealand Government to achieve high levels of compliance with its emergency management plans. For example, the New York Times has observed that New Zealand's Prime Minister sold its people the idea of complying with harsh lockdown restrictions through what it describes as "straight talk and mom jokes". ${ }^{92}$ The New York Times' analysis also highlights something that is not the focus of the present article but is worth noting, namely, the role played by the form of democracy that New Zealand has embraced. Without going into too many details, New Zealand has a "Mixed-Member-Proportional" system of voting, meaning that every New Zealander of voting age gets two votes: one for an electoral MP and one for their preferred party. What usually results is a coalition government, because no single party gains the majority of the votes to govern alone. What that usually means in reality is that New Zealand has a truly representative democracy and one in which the Government of the day must consult, in a spirit of openness, moderation and genuine cooperation, with other political parties. Those political facts have to be kept in the back of one's mind when analyzing the overall response to COVID-19. Had New Zealand not moved to MMP in 1992, had it retained the old "First-Past-thePost" electoral system when given the choice at a referendum that year, it is submitted that it is most unlikely that we would have in place the current government with it inherent and politically necessary practice of consulting and cooperating (whether in times of crisis or not) which arises out of the MMP electoral system.

91 For example, in the United States, the President has recently stated that there will be a temporary end to immigration and the country will close its borders to foreign workers. This seemed like an odd statement given that the borders were virtually closed anyway. Later clarification showed that he meant a restriction on those seeking permanent residency, not temporary workers. In Kuwait, a locally-famous actress called Hayat Al Fahad called for all foreigners in Kuwait to be sent home because she was "fed-up" with them in her country: see Emma Day, " "Put them in the desert': Kuwait actress Hayat Al Fahad under fire for telling expatriates to go home" The National (online ed, 2 April 2020) available at: $<$ https://www.thenational.ae/arts-culture/film/put-them-in-the-desert-kuwaiti-actress-hayat-al-fahadunder-fire-for-telling-expatriates-to-go-home-1.1000595>.

92 Damien Cave, "Jacinda Arden Sold a Drastic Lockdown with Straight Talk and Mom Jokes" New York Times (online ed, 23 May 2020) available at: < https://www.nytimes.com/2020/05/23/world/asia/ jacinda-ardern-coronavirus-new-zealand.html>. 


\section{Section 4. Adjourning Parliament: Establishing the Epidemic Response Committee}

New Zealand adheres to the constitutional principles of having both a representative government and a responsible government. A few observations of what these principles mean in the New Zealand context helps to explain why the Epidemic Response Committee (ERC) was established - and its significance.

One of the key features of representative government is that, according to statute, to become a Minister of the Crown in New Zealand an individual must have first been elected as a Member of Parliament. ${ }^{93}$ Elections for Members of Parliament (MPs) are held every three years and there are 120 MPs in Parliament. It is legally impossible in New Zealand to be appointed as a Minister of the Crown unless one has first been elected as a representative of the people by being elected to Parliament. This is stated in legislation and it is a key feature of Westminster-style democracy as adopted by New Zealand. ${ }^{94}$

One of the features of responsible government is that the Prime Minister and all Ministers of the Crown are collectively responsible to the House of Representatives. The Ministers are responsible to the House because the latter is a body that consists of MPs, elected by the people. In New Zealand, Parliament consists of the Sovereign (or their representative, the GovernorGeneral) and the House of Representatives (that is, the MPs). ${ }^{95}$ There is a constitutional convention in New Zealand which states that the Government must collectively enjoy the confidence of the House of Representatives in order to continue in office. This constitutional convention is not part of any statute - it is not law_-but it is a key part of our constitutional framework, as stated in the Cabinet Manual. ${ }^{96}$ As an aside, the Cabinet Manual is a document

93 Section 6(1) Constitution Act 1986: "A person may be appointed and hold office as a Member of the Executive Council or as a Minister of the Crown only if that person is a Member of Parliament."

94 Section 6(1) Constitution Act 1986 might be compared with, say, Article 56 of the Kuwait Constitution 1962 which provides that "Ministers shall be appointed from among members of the National Assembly, and from other quarters" which means - in reality - that most Ministers in Kuwait are not MPs, and thus most Ministers in Kuwait were not elected to the National Assembly by voters. For this reason, amongst others, it may be argued that Kuwait does not exhibit one of the fundamental characteristics of a Westminster style of government, namely, representative government.

95 Section 14 Constitution Act 1986: "There shall be a Parliament of New Zealand, which shall consist of the Sovereign in right of New Zealand and the House of Representatives."

96 Cabinet Manual 2017 [6.58]: “A basic principle of New Zealand's system of responsible government is that the government must have the confidence of House of Representatives to stay in office. A government may lose the confidence of the House during its parliamentary term." See Cabinet Manual 2017, available at: <https://dpmc.govt.nz/sites/default/files/2017-06/cabinet-manual-2017.pdf>. 
which, although not legally binding, is nonetheless considered as "the primary authority on the conduct of Cabinet government in New Zealand". ${ }^{97}$ Governments occasionally revise and recommit to the rules stated in the Cabinet Manual.

New Zealand's Parliament was adjourned on 25 March, until 2pm on 24 April, due to the COVID-19 virus. ${ }^{98}$ Without a sitting Parliament, the Government was going to be acting throughout that crucial period-when so many important and far-reaching decisions had to be made - without Parliamentary oversight. The problem is obvious: how can Parliament continue to hold the Government accountable and scrutinize its actions at a time when-due to the nationwide lockdown and social distancing measures-Parliament physically cannot sit? This is a problem that every country with a parliament has faced in the past few months. For instance, the Speaker of Kuwait's Parliament announced on 8 March that Parliament would adjourn for two weeks due to the threat of COVID-19.99

In order to continue and uphold the concept of responsible government, and allow Parliamentary scrutiny of the Government during a national emergency such as the current COVID-19 pandemic, the New Zealand Government ${ }^{100}$ arrived at a unique solution. The first step was taken on 19 March when the Leader of the House of Representatives, Chris Hipkins, moved a motion to "facilitate the activities of the House and its activities during the current pandemic". ${ }^{101}$ The Leader of the House proposed a motion to put in place a sessional order that would become part of the House's Standing Orders until the next election (to be held on 19 September 2020). In preparation for the (then) imminent possibility that Parliament may not be able to continue to sit as usual, the sessional order that was passed on 19 March 2020 allowed a number of changes to the way that House operates, essential among them were the following: the Business Committee would be able to meet and make determinations by electronic means, including remote participation; an

97 Ibid, Foreword.

98 Parliament NZ, "Daily Progress for Wednesday, 25 March 2020" Parliament.nz (online, 25 March 2020) available at: <https://www.parliament.nz/en/pb/daily-progress-in-the-house/daily-progress-forwednesday-25-march-2020/>.

99 Kuwait News Agency, "Parliament's Speaker justifies decision to adjourn sessions" KUNA (8 March 2020) available at: $<$ https://www.kuna.net.kw/ArticleDetails.aspx?id=2874837\&language $=$ en $>$.

100 The New Zealand Government, the Sixth Labour Government, is currently a Labour Party-New Zealand First Party coalition. The Green Party is not a coalition partner but it has agreed to give support to the Government on confidence and supply issues.

101 Parliamentary Debates (Hansard) 19 March 2020 available at: <https://www.parliament.nz/en/pb/ hansard-debates/rhr/combined/HansD_20200319_20200319>. 
Assistant Speaker could be appointed who would be able to carry out all the duties of the Speaker or the Deputy Speaker during an adjournment if the latter were both absent from duty; oral questions would be permitted to be lodged electronically; the Business Committee would be permitted to waive or adjust the limit on proxy votes and the Speaker would be permitted to approve special arrangements for select committees to meet, such as meeting by electronic means..$^{102}$

The next major development occurred on 25 March 2020. Parliament met that day to consider a range of important matters before its adjournment. It was an unusual sitting of Parliament in that it was an early sitting at the Prime Minister's request and in the public interest, under urgency, with many MPs absent due to travel restrictions. Prior to the sitting, the Business Committee waived the proxy vote limit. ${ }^{103}$ Three important items of business were dealt with at this sitting of Parliament, each of which is relevant in the context of this paper's focus and is discussed in turn below.

\section{State of emergency notified to the House of Representatives and Epidemic Notice issued}

First, the Prime Minister made a Ministerial Statement informing the House of a state of emergency and moving the country to Alert Level 4. The Prime Minister stated that the Minister of Civil Defence had declared a state of emergency for the whole of New Zealand at $12.21 \mathrm{pm}$ on 25 March 2020 under section 66 of the Civil Defence Emergency Management Act 2002. ${ }^{104}$ In addition, the Prime Minister issued an Epidemic Notice under section 5 of the Epidemic Preparedness Act $2006^{105}$ to ensure the continuity of essential Government business: it came into effect at midnight on 25 March and will remain in place for three months. ${ }^{106}$

102 Parliamentary Debates (Hansard) 19 March 2020 available at: https://www.parliament.nz/en/pb/ hansard-debates/rhr/combined/HansD_20200319_20200319> (see "Standing Orders - Sessional" at that link).

103 Parliament New Zealand, Bills and Laws, "Imprest Supply (Third for 2019/20) Act 2020: Bills Digest 2617" 3 April 2020, available at: <https:/www.parliament.nz/en/pb/bills-and-laws/bills-digests/ document/52PLLaw26171/imprest-supply-third-for-201920-act-2020-bills-digest>.

104 Parliamentary Debates (Hansard) 25 March 2020, "Ministerial Statement - COVID-19 - Move to Alert Level 4 and State of National Emergency" available at: <https://www.parliament.nz/en/pb/ hansard-debates/rhr/combined/HansDeb_20200325_20200325_02>.

105 Section 5 Epidemic Preparedness Act 2006, available at: <http://legislation.govt.nz/act/ public/2006/0085/latest/DLM404483.html>.

106 Parliamentary Debates (Hansard) 25 March 2020, "Ministerial Statement - COVID-19 - Move to Alert Level 4 and State of National Emergency" supra n 105. 


\section{Laws passed to secure Government's COVID-19 related expenditure}

Secondly, the House considered three bills under urgency: the Imprest Supply (Third Bill for 2019/20) Bill, the COVID-19 Response (Taxation and Social Assistance Urgent Measures) Bill and the COVID-19 Response (Urgent Management Measures) Bill were all introduced, then they were immediately voted through their First, Second and Third Readings and were passed into law in one sitting. ${ }^{107}$ Since the House was sitting under urgency, the bills were able to pass through all three stages without select committee scrutiny or submissions from the public (the latter is a normal feature of the select committee process). ${ }^{108}$ Furthermore, the usual three-day stand-down period between introduction of a bill and its first reading was also waived. ${ }^{109}$

Practically speaking, the passing of these three bills into law was essential to ensuring that the Government had authorization to raise money and spend public money to deal with the pandemic and its implications. From a constitutional law perspective, the passing of these three laws had significant importance. It is well known that the "raising and spending of public moneys is one of the original functions of the Westminster Parliament". There is a "constitutional prescription against public spending without parliamentary authorization" and this is a "central feature of Parliament's 'control' function." 110 There is also a statutory obligation under section 22 of the Constitution Act 1986 to obtain Parliament's permission before borrowing or receiving any money or spending public money. ${ }^{111}$ The rule that Parliament must authorize Government spending reaches back to the origins of Parliament itself and is fundamental to democracy: ${ }^{112}$

107 Parliamentary Debates (Hansard) 25 March 2020 available at: <https://www.parliament.nz/en/pb/ hansard-debates/rhr/>.

108 Note that under Standing Order 331, Imprest Supply Bills can pass through all stages in one day, even when there is a non-urgency situation: see Standing Orders of the House of Representatives 2017 [331] available at: <https://www.parliament.nz/media/4384/standing-orders-2017.pdf $>$.

109 Parliament New Zealand, Bills and Laws, "Imprest Supply (Third for 2019/20) Act 2020: Bills Digest 2617" 3 April 2020, available at: < https://www.parliament.nz/en/pb/bills-and-laws/bills-digests/ document/52PLLaw26171/imprest-supply-third-for-201920-act-2020-bills-digest>.

110 Philip Joseph, Constitutional and Administrative Law in New Zealand (4 ${ }^{\text {th }}$ ed, Thomson Reuters, 2014) at 314.

111 Section 22 Constitution Act 1986 provides that: "It shall not be lawful for the Crown, except by or under an Act of Parliament - (a) To levy a tax; or (b) To borrow money or to receive money borrowed from any person; or (c) To spend any public money."

112 New Zealand Parliament, "Government Accountability to the House - Appropriation and Supply of Public Funds" 17 May 2016, available at: <https://www.parliament.nz/en/document/00HOOOCPubR esAboutFactSheetsAccount1\#Appropriation> (emphasis added). 
As far back as 1376 the English House of Lords and House of Commons jointly assembled to refuse supply until grievances about Court expenditure were addressed...The principle of Parliamentary control over supply is fundamental to a democratic system because it ensures the Government must retain the confidence of the House to fund its activities. It cannot remain in power if it fails to obtain supply.

Therefore, the Government had to introduce and then pass these bills into law, before adjourning Parliament. A full discussion of the content of these three laws is beyond the scope of the current paper but in essence the Imprest Supply (Third for 2019/20) Act 2020 permits \$NZ40 billion of operating expenditure, ${ }^{113}$ \$NZ12 billion of capital expenditure, ${ }^{114}$ and up to $\$ N Z 2$ billion in capital injections for any department or office of Parliament ${ }^{115}$ - with the overall objective of allowing the Government to "protect New Zealanders' health and support everybody through the crisis". ${ }^{116}$ The key provisions of the Imprest Supply Act 2020 are that the Government can incur expenses up to \$NZ40 billion (section 7) and capital expenditure up to \$NZ 12 billion (section 8). The Government announced a range of fiscal support measures intended to help New Zealanders including: \$NZ500 million to support the public health response; a 6-month mortgage repayment holiday for anyone whose income is affected by COVID-19 so that no one loses their home; increasing all main government benefits by $\$ 25$ a week; increasing the usual winter energy payment by doubling it; freezing all rent increases and extending no-cause terminations for tenancies; introducing a wage subsidy scheme available to all New Zealand businesses, sole traders and the self-employed of \$NZ585 per week per employee to cushion the blow of having to be isolated at home and having businesses negatively affected by the shutdown, ${ }^{117}$ as well as a range of health-funding initiatives to support the public health system. ${ }^{118}$ Those fiscal support measures were all facilitated by the legislation passed on 25 March 2020.

113 Section 7 Imprest Supply (Third for 2019/2020) Act 2020.

114 Section 8 Imprest Supply (Third for 2019/2020) Act 2020.

115 Section 9 Imprest Supply (Third for 2019/2020) Act 2020.

116 Parliamentary Debates (Hansard) 25 March 2020, "Imprest Supply (Third for 2019/20) Bill Second Reading, transcript available at: <https://www.parliament.nz/en/pb/hansard-debates/rhr/combined/ HansDeb_20200325_20200325_06>.

117 Details of the wage subsidy scheme are available at Employment New Zealand, "Wage Subsidy Scheme" 6 April 2020, available at: <https://www.employment.govt.nz/leave-and-holidays/othertypes-of-leave/coronavirus-workplace/wage-subsidy/\#about>.

118 Ibid. 


\section{Epidemic Response Committee in lieu of a siting Parliament}

Thirdly, the Leader of the House moved that there be established an Epidemic Response Committee. There was no opposition to the motion. The purpose of the Epidemic Response Committee is to "consider and report to the House on any matter relating to the Government's management of the COVID-19 epidemic". The Leader of the House stated in his speech to the House that the motion he was introducing: ${ }^{119}$

...puts in place a mechanism, whereby the Opposition in particular, will be able to continue to scrutinize the Government and the actions that the Government is taking, even though the House will not be sitting. A special select committee is being established. It will have an Opposition majority, which recognizes these extraordinary circumstances we are in. It will be chaired by the Leader of the Opposition. It will have the power to require people to appear before it - albeit digitally, rather than in person. They will be able to request and receive information about the use of the powers that the Government has been exercising, and I think those things are vitally important in our democratic system.

It is hard to underestimate the importance of what this motion signifies. At the time when the Government could take advantage of its position, and suspend Parliament for a considerable period of time, it instead took the initiative to protect the constitutional convention of responsible government by setting up a select committee, chaired by the Leader of the Opposition (the National Party), with the purpose of holding itself to account. The purpose of the Epidemic Response Committee was to make sure that it - the Government-was held to account for its decisions during the period in which Parliament could not sit. It must be noted that the Government established the Epidemic Response Committee in the same sitting and just before it adjourned Parliament, so that there would not be any gap in Parliamentary oversight of the Government.

The practical implementation of this innovation is also interesting. The Epidemic Response Committee had nine members in total: five members from the Opposition and five members from the Government, and, since the Chair of the Committee was the Leader of the Opposition, that means that the Opposition held the majority. The Epidemic Response Committee met three

119 Hansard, "Business of Select Committees - Epidemic Response Committee" Parliament (25 March 2020) online transcript available at: $<$ https://www.parliament.nz/en/pb/hansard-debates/rhr/combined/ HansDeb_20200325_20200325_24>. 
days a week at 10am on Tuesdays, Wednesdays and Thursdays via videoconference. Those video-conferences are streamed live on Parliament TV and on Parliament's Facebook page. Thus, the meetings could be viewed livestreamed or as downloaded files by anyone in the world. ${ }^{120}$

The first public meeting of the Epidemic Response Committee via video conference was held on 31 March. ${ }^{121}$ It was largely focused on the health issues associated with the pandemic and as such most of the invited presenters were health officials. On 1 April the focus was on the Government's economic response and on 2 April it was on Police, Civil Defence and Customs responses. The Chairperson could call anyone to appear before the Epidemic Response Committee to hear their expert opinions and to help ensure that it carried out its role in scrutinizing the Government on behalf of the people of New Zealand.

It is submitted that this initiative-the establishment of the Epidemic Response Committee by the Government to hold itself accountable whilst Parliament could not-was an act of genuine courage and creativity. It demonstrated the Government's commitment to the core values of democracy. It also demonstrated the Government's commitment not just to responsible government but also to open government. It showed that the Government was keen to see that democracy survived and indeed thrived despite the physical limitations created by pthe COVID-19 crisis.

How significant is this? It may not be immediately obvious to observers from other jurisdictions, but in New Zealand, the Government's loudest and most constant critic is the party (or parties) that lost the last election and found themselves, post-election, as part of the political opposition in the House of Representatives. That makes it even more remarkable that the Leader of the Opposition, who was also the Leader of the National Party at the time- - Simon Bridges - would write an article published in the British press, extolling the virtues of the Government's actions in establishing the Epidemic Response Committee. Bridges had actually wanted Parliament to continue sitting, rather than adjourn, but the Epidemic Response Committee was a compromise. Bridges commented that "this committee has been crucial to ensuring the New

120 Parliament New Zealand "Watch public meetings of the Epidemic Response Committee" available at: $<$ https://www.parliament.nz/en/pb/sc/scl/epidemic-response/news-archive/watch-public-meetingsof-the-epidemic-response-committee/>.

121 Radio New Zealand News "Epidemic Response Committee to hold first public meeting today" $R N Z$ (online ed, 31 March 2020) available at: <https://www.rnz.co.nz/news/political/412985/epidemicresponse-committee-to-hold-first-public-meeting-today>. 
Zealand response is better than it otherwise would have been."122 Bridges' public support for the Epidemic Response Committee was important. The Government could have appointed anyone to Chair the Committee, but it appointed the Leader of the Opposition, normally its harshest critic.

Since the first draft of this article was written on 25 April 2020, the Leader of Opposition - Simon Bridges - has been replaced by means of a coup inside his own political party. The success of the Labour-led Government in dealing with COVID-19 lead to public opinion polls predicting a likely landslide victory for the Government at the upcoming September 2020 election. Therefore, the National Party voted out Simon Bridges as Leader of the National Party and replaced him with MP Todd Mueller, with the hope of increasing the party's popularity before the upcoming election. ${ }^{123}$ This development is a direct consequence of how popular the Government is, in light of its handling of the COVID-19 pandemic.

\section{Critique of the Government's response}

As one might expect in a free and open democracy, not everyone is entirely satisfied with the New Zealand Government's efforts at maintaining transparency and accountability. The New Zealand Law Society, for instance, has written to the Chair of the Epidemic Response Committee to note that whilst it appreciates that at this time "governments might need to use the law in ways we do not normally accept" but " $[t]$ his does not mean that the rule of law is any less important; in many ways the rule of law is more important now than ever before." 24 The New Zealand Law Society has called on the Government to provide "clarity on the restraints on our usual freedoms of movement and association and on commerce, and clarity about the legal basis for these constraints...". As for the adjournment of Parliament, the New Zealand Law Society has said that "[c]onsideration also needs to be given to reconvening Parliament, if that can be done in a safe way, before the end

122 Simon Bridges "In the absence of Parliament we must ensure that New Zealand's response to COVID-19 is the best that it can be" The Guardian (online ed, 3 April 2020) available at: <https:// www.theguardian.com/commentisfree/2020/apr/03/in-the-absence-of-parliament-we-must-ensurenew-zealands-response-to-covid-19-is-the-best-it-can-be>.

123 Jenna Lynch, "National MPs have mixed feelings as Todd Mueller takes over as leader" NewsHub (online ed, 22 May 2020) available at: <https://www.newshub.co.nz/home/politics/2020/05/nationalmps-have-mixed-feelings-as-todd-muller-takes-over-as-leader.html $>$.

124 New Zealand Law Society, "Letter to Hon Simon Bridges MP" 4 April 2020, available at: <https:// www.lawsociety.org.nz/_data/assets/pdf_file/0009/145197/1-Epidemic-Response-CommitteeCovid-19-4-4-20.pdf $>$. 
of the currently notified Level-4 period, and certainly if it is extended." 125 Aside from the New Zealand Law Society, there have been some critical political commentators making their voices heard in the usual ways - through articles in the media and appearances on television - objecting to aspects of the Government's approach (e.g. the extent and duration of the lockdown). ${ }^{126}$ This criticism is invaluable in an open and free democracy and is what citizens accept, and indeed expect, as the media plays its role in holding the Government accountable, an issue that is discussed further below. ${ }^{127}$ Certainly, no journalists have been threatened with arrest or indeed any lesser sanctions for playing their role in criticizing the government's response whenever they thought it appropriate to do so. This, it is submitted, is one of the ways that the media can help to hold the government accountable: by examining the Government's every move and calling it out when they believe it is wrong.

\section{The United Kingdom: Parliament in recess}

Other countries, such as the United Kingdom, have given a "stamp of approval" to New Zealand's example. Perhaps the most interesting source of admiration is that of the United Kingdom because New Zealand's Westminster style of government is modelled on the United Kingdom. ${ }^{128}$ It seems that in the face of the COVID-19 pandemic, the UK allowed its Parliament to take an early recess. The United Kingdom's Ed Davey, Acting Leader of the Liberal Democrats, called on the UK Government to create a select committee for the COVID-19 virus, a virtual Parliament, made up of members of the Opposition and the Government, along the same lines as New Zealand's Epidemic Response Committee. In a letter to the Commons' committee, reported in "The Guardian" Davey argued that: ${ }^{129}$

125 Ibid.

126 For two examples of the critique in the media see Mike Hosking, "Government has overcooked the lockdown" NZ Herald (online ed, 21 April 2020) available at: https:/www.nzherald.co.nz/nz/ news/article.cfm?c_id=1\&objectid=12326281 and see Barry Soper "Lockdown decision shows this Government isn't business savvy" NewsTalkZB (online ed, 21 April 2020) available at: $<$ https://www. newstalkzb.co.nz/opinion/barry-soper-lockdown-decision-shows-this-government-isnt-businesssavvy/>.

127 See discussion below under the heading "The role of the media in holding the Government to account".

128 New Zealand was a British colony from 1840 when the Treaty of Waitangi was signed. Its date of independence is the subject of some scholarly debate but could be taken as 25 November 1947 when New Zealand passed the Statute of Westminster Adoption Act 1947. New Zealand is still a member of the Commonwealth of Nations.

129 Kate Proctor, "MPs call for 'virtual Commons' amid COVID-19 early recess" The Guardian (online, 31 March 2020) available at: <https://www.theguardian.com/politics $/ 2020 / \mathrm{mar} / 31 / \mathrm{mps}$-call-forvirtual-house-of-commons-amid-covid-19-early-recess $>$. 
If it wasn't a dangerous infectious virus but a major emergency, Parliament would have been recalled... We think scrutiny is good for Government policy.

Ed Davey specifically called out the example set by New Zealand: ${ }^{130}$

The precedent for this has already been set by New Zealand, in a parliament and a democracy largely based on our Westminster model. This could in turn now act as a model for the UK. Such a system would ensure continued Parliamentary scrutiny of government decisions...

Other individuals in the United Kingdom made similar points about the need for Parliament to continue its oversight role. Darren Hughes, chief executive of the Electoral Reform Society, said that: ${ }^{131}$

Ministers and public officials must be held to account by those with a full suite of powers to call evidence...Cabinet is showing that politics can continue to function during this crisis. Parliament must show the same, with the Speaker leading the way in providing accountability at this hour.

Hughes' point is that if Cabinet can continue its role, then so can Parliament. Adjustments have been made so that Cabinet can meet virtually, using videoconferencing tools such as Zoom, so the challenge he is posing is for Parliament to adjust and to likewise continue its role in scrutinizing Government action. This is a point that surely must apply to all countries claiming to uphold democracy, whether they follow the Westminster model or otherwise. Citizens of all countries ought to be asking the same questions that Davey and Hughes have been asking in the United Kingdom: why isn't Parliament able to continue its role throughout this crisis? Why can't some flexibility be embraced so that all Parliaments can continue to scrutinize government action and hold the latter accountable for their decisions? It is a time for co-operation, as the Speaker of the Kuwaiti Parliament recently asserted. ${ }^{132}$ But more importantly it is a time

130 Ed Davey, "It's time to virtually recall Parliament with a COVID-19 committee" The NewStatesman (online ed, 3 April 2020) available at: <https://www.newstatesman.com/politics/uk/2020/04/its-timevirtually-recall-parliament-covid-19-committee>.

131 Kate Proctor, "MPs call for 'virtual Commons' amid COVID-19 early recess" The Guardian (online, 31 March 2020) available at: <https://www.theguardian.com/politics/2020/mar/31/mps-call-forvirtual-house-of-commons-amid-covid-19-early-recess $>$.

132 Kuwait News Agency (KUNA), "Kuwaitis must act as one against COVID-19 - AlGhanim" KUNA (16 March 2020) available at: <https://www.kuna.net.kw/ArticleDetails. aspx?id $=2879501$ \&language $=\mathrm{en}>$. 
for accountability and transparency, and for that to occur, Parliament needs to have an active role and be able to fully participate. To that end, the United Kingdom's House of Commons agreed on 16 April to an approach that has never before been tried in its 700-year history: it is going to sit with reduced numbers in the House (around 50 Ministers and backbenchers will be allowed in the House at any one time) and the rest will join online, via Zoom. ${ }^{133}$ This hybrid model of Parliament, put forward by the Commons Commission, is still under development and further research on how this works will be necessary. The hybrid model (some MPs sitting physically and some remotely via Zoom) is, at the time of writing, intended as a means of moving towards an entirely online Parliament. ${ }^{134}$ It is submitted that this is a positive development and one that every Parliament ought to consider: there are other conceivable reasonsaside from COVID-19-which could prevent Parliament from physically sitting (such as a natural disaster) and it seems wise to have processes ready to be implemented to enable Parliament to continue its job of scrutinising the executive and passing legislation.

\section{Australia calls for a New Zealand-style COVID-19 committee}

Australia's Parliament sat with heavily reduced numbers on 23 March 2020 to pass an \$AU66 billion stimulus package and then it entered into a recess: Parliament won't sit again until 11 August. ${ }^{135}$ Despite objections from the Opposition, this development means that, potentially, the Government will have no Parliamentary oversight during a period of extremely important decision-making, especially in terms of deciding how to spend the billions of dollars that was approved prior to the recess.

Australian lawyers and judges have also referenced the New Zealand example. A group of former judges have called for the establishment of a bi-partisan select committee COVID-19 initiative like New Zealand. The group of former judges noted that: ${ }^{136}$

133 Peter Walker, "Slimmed-down virtual House of Commons to sit next week" The Guardian (online ed, 16 April 2020) available at: < https://www.theguardian.com/politics/2020/apr/16/slimmed-downvirtual-house-of-commons-to-sit-next-week $>$.

134 Ibid.

135 SBS News, "Federal Parliament to shut until August as coronavirus causes revised schedule" SBS News (online edition, 23 March 2020) available at: <https:/www.sbs.com.au/news/federal-parliament-toshut-until-august-as-coronavirus-causes-revised-schedule $>$

136 The Australian Institute, "Former Judges Call for the Establishment of NZ-style Multi-Partisan COVID-19 Parliamentary Oversight Committee" (online, 1 April 2020) available at: < https:/www. tai.org.au/content/former-judges-call-establishment-nz-style-multi-partisan-covid-19-parliamentaryoversight $>$. 


\begin{abstract}
Like Australia, New Zealand has shut down its Parliament due to COVID-19. However, NZ has found a non-partisan alternative to maintain accountability...The establishment of such a committee represents a clever and principles compromise between the Government, which has rightly closed Parliament for public health reasons, and Opposition Parties, which equally rightly want Parliament sitting to hold Government accountable for its actions in a time of such crisis.
\end{abstract}

Both Australia and the United Kingdom have a situation where their Parliaments are in recess: Australia until 11 August; the United Kindgom until at least 21 April. The political parties in their respective Parliaments, who are tasked under the convention of responsible government, of scrutinising government action and providing oversight, are physically unable to do so. Both have called for their respective governments to consider a NZ-style virtual/online select committee model to provide some form of continuing oversight.

It is argued here that there is an obligation for every government to provide such an oversight mechanism - perhaps along the lines of the New Zealand model. It should be virtual/online, it should be public, and it should be led by the leader of the opposition with members from all political parties. If Parliament cannot sit because of a public emergency, that does not excuse the New Zealand Government, nor any government, from providing a means for oversight to continue. New Zealand has shown the way and is currently demonstrating what is possible: the constitutional convention of responsible government can be preserved, and democracy can be protected, even in times of a state of emergency, such as the one presented by COVID-19.

\title{
Section 5. The role of the media in holding the Government to account
}

An important part of any functioning democracy is a free media. It is wellaccepted that "public opinion is a critical check on governmental and parliamentary power". ${ }^{137}$ The role of the media is even more important at a time of national crisis. Transparency and accountability are absolutely essential for a properly functioning democracy, to ensure that the government is communicating accurate information and making decisions that are in the best interests of the people. The media is the crucial link between what the Government is doing, and what the public know about what the Government

137 Philip Joseph, Constitutional and Administrative Law in New Zealand (4th ed, Thomson Reuters, 2014) at 556. 
is doing. As Karl du Fresne wrote in 2009:138

...democracy cannot make sense without some means of informing the public on the affairs of government. Representative democracy not only requires that the public know what their elected representatives are doing, but also depends on those representatives knowing what the public thinks. The press is the vital two-way link in the democratic chain without which the public cannot engage in the political process.

New Zealanders have high expectations when it comes to both access to information and freedom of expression. We expect that two-way link to operate freely, openly and effectively. We expect our politicians to keep us informed of what they are doing, and what they plan to do. We expect to be able to obtain any official information we desire, through making an Official Information Act request if necessary, and we expect to be able to express ourselves freely on talk-back radio, in newspaper columns, in letters to the editor, on Facebook, Twitter, and all the other social media platforms.

For example, on 21 March 2020, the Leader of the Opposition, Simon Bridges, posted a message on his Facebook page criticizing the Government for extending Alert Level 4 for two additional weeks. In response, he received approximately 16,000 comments, most of them negative and calling him out for being "tone-deaf" and out of touch with New Zealanders' concerns. ${ }^{139} \mathrm{He}$ in return posted that "there are a bunch of different views" asserting that everyone is entitled to their opinion. Indeed, that is exactly what New Zealanders would all agree on: everyone is allowed to express their opinion freely and no one should be penalized for doing so. That is a mark of a functioning democracy.

\section{Freedom of expression and COVID-19: the good, the bad and the ugly}

A crisis like COVID-19 is like a stress-test for a country's respect for its own people's constitutional rights: COVID-19 shows up the best and the worst in governments, and it tests their ability to hold firm to the fundamental characteristics of a democracy; the free-flow of information becomes even more important than usual in a global health crisis such as the current one.

138 Karl du Fresne, "The Uninvited Guest: The Role of the Media in an Open Democracy" (2009) 54 Yearbook of New Zealand Jurisprudence 52 at 56 (emphasis added). Du Fresne was the former editor of the Wellington daily newspaper The Dominion.

139 NZ Herald, "COVID-19 Coronavirus: Simon Bridges Facebook post criticising lockdown extension slammed" NZ Herald (online ed, 21 April 2020) available at: <https://www.nzherald.co.nz/nz/news/ article.cfm?c_id=1\&objectid $=12326485>$. 
Examples from around the world show that in terms of permitting freedom of expression, there is a wide range of practices being followed, from the good to the bad to the ugly.

If people are penalized merely for criticizing their government's actions or inactions, then it is submitted they are not living in a democracy: they are instead living in (at best) a semi-democracy, or (at worst) an autocracy or a dictatorship. Recent news stories emanating from Kuwait, Jordan, Egypt and Iraq in relation to COVID-19 media coverage suggest that freedom of expression is under attack in the Middle East and North Africa, as it is elsewhere. Television presenters, reporters and television channel owners are being arrested for simply expressing their opinions.

A few examples show that COVID-19 is provoking a special clamp-down on the freedom of the press. In Kuwait, the Attorney-General was reported to have ordered the arrest of Kuwaiti television presenter Dalia Badran on 19 April for "insulting the country and its armed forces" in a tweet. ${ }^{140}$ A few days earlier in Jordan, authorities arrested Roya TV Channel's owner Fares Sayegh, and its news director and presenter, Mohammed Al Khalidi, for broadcasting a report in which Jordanians from a poor neighbourhood criticized the government because they were suffering financial difficulties due to COVID-19. The two men were reported to be spending 14 days in prison for their "crime" of reporting on what some of the poorest people of their country were experiencing. ${ }^{141}$

In Jordan on 17 March 2020, King Abdullah reportedly approved an emergency "defence law" which gives the Prime Minister sweeping powers to "deal firmly with anyone who spreads rumours, fabrications or false news". ${ }^{142}$ In Egypt, on 11 April 2020, the government blocked the website of Egyptian news outlet "Darb" which is owned by the opposition Socialist Popular Movement Party, and the website was apparently unavailable on all internet providers in Egypt. ${ }^{143}$ On 14 April, the Iraqi government suspended the licence of the Reuters news

140 Middle East Monitor, "Kuwait arrests tv presenter for 'insulting army' Middle East Monitor (online ed, 20 April 2020) available at: <https://www.middleeastmonitor.com/20200420-kuwait-arrests-tvpresenter-for-insulting-army/>.

141 MEE Staff, "Coronavirus: Owner of TV channel Roya arrested over report" Middle East Eye (online ed, 10 April 2020) available at: < https://www.middleeastmonitor.com/20200420-kuwait-arrests-tvpresenter-for-insulting-army/>.

142 International Press Institute, 25 May 2020 update, available at: <https://ipi.media/covid19-mediafreedom-monitoring/>.

143 International Press Institute, "COVID-19: Number of Media Freedom Violations by Region” April 2020 available at: $<$ https://ipi.media/covid19-media-freedom-monitoring/>. 
agency "after it published a story saying the number of confirmed COVID-19 cases in the country was higher than officially reported". ${ }^{144}$

Persecution of members of the press is completely incompatible with human rights and the values embraced by democracies. The abovementioned examples by governments in the Middle East and North Africa are incompatible with a basic understanding of the international human right called "freedom of expression". These actions are, arguably, not even compatible with the constitutions of those countries, although a thorough examination of that argument is beyond the scope of the current article. ${ }^{145}$

Although states are permitted to make reservations to the international conventions that protect freedom of expression, states are not permitted to make reservations, or subsequently enact domestic legislation, that defeats the purpose of the international convention to which the state has already committed itself. That much is guaranteed by Article 18 of the Vienna Convention on the Law of Treaties $1969 .{ }^{146}$ Article 18 provides that "a State is obliged to refrain from acts which would defeat the object and purpose of a treaty" when it has expressed its consent to be bound by that treaty.

Thus, even if a state's legislative body passes a law which purports to give the Government the "legal" power to arrest television presenters, journalists or citizen bloggers for merely reporting the news or expressing political opinions, or passes a law that allows for the closure of media outlets, there is a very good argument, pursuant to Article 18 of the Vienna Convention, that such a law would be incompatible with that state's international law obligations if that state has, for instance, ratified the International Convention on Civil and Political Rights. A full exploration of the potential human rights violations of individual states during the COVID-19 pandemic is beyond the scope of the current research and may be the focus of future scholarly endeavours. Suffice to say here that national constitutions and laws ought to protect and further — not suffocate and extinguish — fundamental human rights

144 Ibid.

145 Article 36 of the Kuwait Constitution 1962 states that "Freedom of opinion and scientific research is guaranteed" and Article 37 states that "Freedom of the press and of publication is guaranteed...": see Kuwait Constitution 1962 available at: <https://www.constituteproject.org/constitution/Kuwait_1992. pdf?lang=en>. Similarly, Jordan's Constitution 1962 states in Article 15 that "The State shall guarantee freedom of opinion; and every Jordanian shall freely express his opinion by speech, writing, photography, and the other means of expression, provided that he does not go beyond the limits of the law". I would argue that the arrests in Kuwait and Jordan, mentioned above, breach both the spirit and the letter of their respective constitutional guarantees of freedom of expression.

146 United Nations, Vienna Convention on the Law of Treaties, 23 May 1969, UNTS Vol 1155, p331, available at: $<$ https://treaties.un.org/doc/Publication/UNTS/Volume\%201155/volume-1155-I-18232English.pdf $>$. 
such as the right to freedom of expression. Furthermore, countries which do not persecute journalists for expressing their opinions are, by and large, much more successful at combatting COVID-19 than those which are attempting to stifle freedom of expression. As the New Zealand example has clearly shown, it is entirely possible - and probably essential - to achieve success in the struggle to control COVID-19 whilst also upholding every person's right to the freedom of expression. There have been plenty of voices of criticism in New Zealand - but the Government has largely encouraged them, and often listened to them, to ensure that its response is as good as it can be.

It is noteworthy that merely having a written national constitution which states that freedom of expression is protected by it, is no guarantee that such a right actually exists. This is particularly interesting in the New Zealand context because, as was mentioned earlier, it is one of only three countries which does not have a codified, written constitution, yet the right to freedom of expression is still very well-protected, especially when compared with other countries which do purport to protect that right in their constitutions. ${ }^{147}$

The International Press Institute (IPI) is one organization that has been tracking the number of media freedom violations by region in the context of the COVID-19 pandemic. Since the COVID-19 pandemic emerged, it has recorded 213 violations of media freedom. It has found that in terms of the number of arrests/charges, the Asia-Pacific and Africa regions are the worst regions to be reporting from on the pandemic, with 25 incidents and nine incidents recorded respectively; the Middle East and North Africa (MENA) region so far has only four recorded arrests but the IPI does not record every arrest - for instance, the arrest of the Kuwaiti television presenter, mentioned above, is not present in its dataset. ${ }^{148}$ In terms of censorship, Asia-Pacific and Africa have nine reported incidents each, and the Middle East and North Africa have four incidents each. ${ }^{149}$ In addition to these statistics, the IPI has been following stories of press freedom violations around the world to highlight how some government have been using COVID-19 as a means to crack down on the freedom of the press. ${ }^{150}$

147 For a discussion of how the right to freedom of expression is protected in New Zealand, see Karl du Fresne, supra n 139.

148 Reporting on the International Press Institute's website is current to 23 May 2020 so the latest arrest in Kuwait has not been added, at the time of writing. Therefore, the figure for the Middle East and North Africa will likely rise.

149 International Press Institute, "COVID-19: Number of Media Freedom Violations by Region” April 2020 available at: $<$ https://ipi.media/covid19-media-freedom-monitoring/>.

150 International Press Institute, homepage, available at: $<$ https://ipi.media/\#>. 
New Zealand always ranks fairly well on international comparisons of press freedom. Not all democracies do, and not all countries that claim to be "democracies" protect freedom of expression and access to information. In the 2020 World Press Freedom Index, New Zealand is ranked as the $9^{\text {th }}$ best country in the world for press freedom. ${ }^{151}$ In relation to the current situation, the New Zealand Government has recognized the importance of not only keeping the public well-informed during the COVID-19 pandemic, but it has also recognised the importance of the media having continuing access to the Government, to ask hard questions and to hold it to account for its decisions. To that end, New Zealand's PM has almost always been present at the live daily press briefings held at the Beehive, since 16 March 2020. The daily press briefings are broadcast live on television and online via Facebook. ${ }^{152}$ Links to previous press conferences are made available online. ${ }^{153}$

Most of these live press briefings begin with a statement from Prime Minister Arden or from the Director-General of Health, Dr Ashley Bloomfield, the latter outlining the most recent information on COVID-19 cases. Both of them give statements if they are both present. Sometimes, only Dr Ashley Bloomfield or another official has fronted at the press conferences, especially during the weekends. The prepared statements usually provide updates on the number of new confirmed cases and suspected cases, the number of recovered patients, the number of deaths and details about any new "clusters" of cases.

The press conferences are factual and "to the point". There are also details about hospital supplies and ability to cope with new COVID-19 cases. Then the brief pre-prepared statements are followed by questions from reporters who represent all media outlets. Due to social-distancing rules, the reporters are spread out, which can be observed due to the live video feed of the press conference. Generally speaking, the prepared statements by Arden and Bloomfield, and sometimes others including the Minister of Finance (Grant Robertson), the Police Commissioner and the Director of Civil Defence Emergency Management (Sarah Stuart-Black), only take up about the first $25-35 \%$ of the press conference. Approximately $65-75 \%$ of the time is usually

151 Norway, Finland and Denmark are the top three countries for press freedom according to the 2020 World Press Freedom Index available at: $<$ https://rsf.org/en/ranking $>$. As a point of comparison in the context of this paper, Kuwait ranks $109^{\text {th }}$, Qatar ranks $129^{\text {th }}$, United Arab Emirates ranks $131^{\text {st }}$, Oman ranks $135^{\text {th }}$ Bahrain ranks $16^{\text {th }}$ and Saudi Arabia ranks $170^{\text {th }}$.

152 Facebook, "Jacinda Arden" available at: <https://www.facebook.com/jacindaardern/ videos/936606563463388>

153 Beehive.govt.nz "COVID-19 Updates" available at: <https://www.beehive.govt.nz/feature/covid-19updates>. 
taken up by subsequent questions from reporters. ${ }^{154}$ Written transcripts of the press conferences are available online, as are video recordings. The questions asked by reporters are often critical or information-seeking: there are no limits on what they can ask. The PM and the Director-General of Health provide answers. This is an example of transparency and openness in government, something which the New Zealand public expects.

In terms of atmosphere, the press briefings are serious and informative, but there is a genuine element of friendliness and sometimes even humour. For example, an interesting situation arose when the Prime Minister responded to the NZ Herald's political reporter, Jason Walls, who started to ask her a question, and then forgot what his questions was. The Prime Minister replied to the reporter: "Don't worry, we'll come back to you. I do worry that you are getting enough sleep Jason." 155 This interaction was a light-hearted interaction that in many ways demonstrates not only the "friendly and folksy" vibe that the Prime Minister often aims for, but also the relationship between the Prime Minister and the reporters who attend press briefings. The reporter himself said that "[i]t's heartening to see civility in leadership". ${ }^{156}$

The media reports of this interaction were largely ones of surprise - and in the US, the theme was largely admiration that we have a Prime Minister who seems to like and respect reporters. ${ }^{157}$ This is thrown into sharp contrast with the US President's comments to media reporters which, at times, can be insulting and combative. President Trump's remarks to reporters at the press briefing on Monday 13 March 2020 stand out as being particularly insulting and demeaning towards reporters who have the task of asking him

154 This estimate of how each press conference is divided, into prepared statements and questions from the media, is based on a reading of a random sample of transcripts. If a transcript is 8 pages long, the prepared statements might have taken up 3 pages and the remaining 5 are questions. It is not based on a reading of every transcript. It is simply provide to give an indication of the way that the press conferences are carried out. The point is that there is a genuine ability for the media to question the Government and receive answers. This may be contrasted with the practice in other countries where perhaps there are no daily press briefings so the Government does not have to answer questions from the media in a public and transparent way.

155 NZ Herald, "COVID-19 coronavirus: Americans lose it over Jacinda Ardern's light-hearted media moment" NZ Herald (online ed, 17 April 2020) available at: <https://www.nzherald.co.nz/nz/news/ article.cfm?c_id=1\&objectid=12325405>

156 James Pasley, "New Zealand Prime Minister Jacinda Arden told a reporter who forgot his questions that she was worried he was not getting enough sleep" Australian Business Insider (online ed, 17 April 2020) available at: < https://www.businessinsider.com.au/jacinda-ardern-new-zealand-worriedreporter-sleep-2020-4?r=US\&IR=T $>$.

157 For a sample of Twitter and international reaction see, for example, NZ Herald, "COVID-19 coronavirus: Americans lose it over Jacinda Ardern's light-hearted media moment" NZ Herald (online ed, 17 April 2020) available at: $<$ https://www.nzherald.co.nz/nz/news/article.cfm?c_id=1\&objectid=12325405> 
questions, on behalf of the American people, in order to hold their government to account. ${ }^{158}$

\section{Democracy and disability}

To ensure that every New Zealander can understand the Government's response, a sign language interpreter joins the Prime Minister and the DirectorGeneral of Health on stage at every live press briefing. Sign language is an official language of New Zealand, with around $0.5 \%$ of the population using it to communicate. ${ }^{159}$ The sign language interpreters provide an invaluable service to those New Zealanders who live with a hearing disability: they can follow the live press conference with every other New Zealander. The Prime Minister, explained their involvement as follows: "Remember, their [the sign language interpreters'] singular focus is to make sure as many New Zealanders as possible know what is going on, not just here, in Parliament, but in New Zealand and around the country." 160

Having a sign language interpreter at press conference is apparently not a universal practice. In the United States, for instance, there is no sign language interpreter standing next to President Trump at his daily press conferences. This is something that the deaf community of the United States are acutely aware of. Joyce Karam, the Washington Correspondent for The National UAE newspaper, tweeted about the New Zealand sign language interpreters, and one user noted that "[d]eaf Americans have sent THOUSANDS of requests for the White House to provide interpreters and have been completely ignored." 161 Indeed, deaf Americans have referred to the lack of sign language interpreters

158 At the 13 April White House briefing, CBS reporter Paula Reid asked a challenging question of President Trump, and he responded by cutting her off and saying: "You're so disgraceful. It's so disgraceful the way you say that". When she asked a follow-up question, President Trump replied: "You know you're a fake, your whole network is a fake and the way you cover it is a fake...": see Poppy Noor, "Has Trump finally met his match? The female reporters setting him straight" The Guardian (online ed, 14 April 2020) available at: <https://www.theguardian.com/us-news/2020/ apr/14/trump-paula-reid-coronavirus-briefing-female-reporters $>$.

159 Note that English is the de facto official language of New Zealand but that is not stated in any legislation. Two language have special statutory status: Maori and Sign Language. Section 3 Maori Language Act 1987 declares Maori language to be an official language of New Zealand. Section 5 New Zealand Sign Language Act 2006 declares New Zealand Sign Language to be an official language of New Zealand. New Zealand was the first country in the world to declare Sign Language as an official language.

160 Megan Harvey, "COVID-19 coronavirus: New Zealand's new her (and it's not Ashley Bloomfield)" NZ Herald (online ed, 17 April 2020) available at: <https://www.nzherald.co.nz/nz/news/article. cfm?c_id $=1$ \&objectid $=12325453>$.

161 Twitter, Joyce Karam, reply from Little Hippie House to Joyce Karam (Twitter, 15 April 2020) available at: < https://twitter.com/joyce_karam/status/1250105500936658944> (emphasis in the original). 
at White House press briefings as "extremely frustrating". Some American state governors use sign language interpreters, others do not. This is a simple issue of access to information for all, regardless of one's disability.

If a country is claiming the title of "democracy" for itself, then it is argued that two essential requirements flow from such as assertion. First, the government must practice accountability and transparency. That means, it must hold regular, public press conferences where it can explain its actions and then be patiently questioned by the media (on behalf of the public) about those actions. Many countries do not hold daily press briefings-they may just issue press statements which an obedient press must publish. Alternatively, if they do hold daily press briefings, there may be a tendency to belittle the role of the press. ${ }^{162}$

Second, the information that is communicated by the government in daily press briefings must be accessible to all, including those with disabilities, such as people with hearing impairments. A sign language interpreter shouldn't be seen as an optional extra, but as an essential part of ensuring that every person in every state and every country (as the case may be) has access to live information - which in a pandemic could be life-threatening or life-saving information.

This section of the paper has explored the constitutional dimensions of the COVID-19 pandemic by focusing on the role of the media, the public's "right to know" and the public's right to express opinions freely. It has examined the way in which governments, such as the New Zealand Government, can opt to put in place systems and procedures - such as the Epidemic Response Committee and daily press briefings - to ensure that, even in extreme situations such as the present, governments can still make sure they are scrutinized and held to account for their actions. It is submitted that the post-COVID-19 world will be different, and the ability of reporters to tell the public what the government is doing, will be challenged by the way that governments react to the current pandemic. One of the casualties of COVID-19 may be the public's ability to express their opinions and to hold their government accountable for their decisions. As the Secretary-General of the NGO Reporters Without Borders, Christophe Deloire, recently stated when it released its 2020 World Press Index report in April:

162 The obvious example here is the United States, where the President of the United States has recently taken a combative stance with reporters in response to the latter asking him questions during press briefings. For examples of the reporting on this trend, see David Smith "Wounded by media scrutiny, Trump turned a briefing into a presidential tantrum" The Guardian (online ed, 14 April 2020) available at: <https://www.theguardian.com/us-news/2020/apr/13/trump-coronavirus-meltdownmedia-authority>. 
The coronavirus public health crisis provides authoritarian governments with the opportunity to implement the notorious 'shock doctrine'. They are taking advantage of the fact that politics is on hold, the public is stunned and protests are out of the question to impose measures that would be impossible in normal times. This is the case in China (177 th) and in Iran (down 3 at $\left.173^{r d}\right)$.

Reporters Without Borders says that the "180-country index notes a correlation between a country's ranking and its response to the pandemic." Thus, both China and Iran have ranked poorly at 177 and 173 respectively in part because of their censorship of the coronavirus outbreaks. ${ }^{163}$

\section{Section 6. Conclusion and recommendations}

The COVID-19 pandemic has opened up a range of constitutional law questions. This paper has sought to identify and answer just a few of them. It has primarily examined the response of the New Zealand Government to the COVID-19 pandemic by focusing on three key areas that touch on constitutional law: the Government's response to the pandemic including its use of its statutory powers under a State of National Emergency; the way in which Parliament has managed to retain a degree of power to scrutinize the executive branch through the establishment of the Epidemic Response Committee; and the important role of the press in ensuring that governments continue to provide full access to information and allow the public to be well-informed at all times in relation to all aspects of the Government's crisis response.

This paper has tried to map out the key developments in each of these areas, as it pertains to New Zealand, because New Zealand has been held up by experts and media observers as having managed the crisis successfully. ${ }^{164}$ A report in the New York Times on 24 March 2020 remarks that Australia and New Zealand have taken a "non-political approach [that] is restoring democracy". ${ }^{165}$

That, of course, does not mean that everything New Zealand has done has been spot on - there will be plenty of areas to improve upon. Hopefully, as the virus is brought further under control and as life returns to a post-COVID-19

163 BBC, "Coronavirus further threatening media freedom, says Reporters Without Borders" BBC News (online ed, 21 April 2020) available at: <https://www.bbc.com/news/world-52363305>.

164 See discussion above regarding American epidemiologist Larry Brilliant's "A" grade for New Zealand at footnote 11 and associated text.

165 Damien Cave "Vanquish the virus? Australia and New Zealand aim to show the way" New York Times (online ed, 24 April 2020) available at: <https://www.nytimes.com/2020/04/24/world/australia/newzealand-coronavirus.html>. 
"new normal", there will be further research and analysis of what can be learnt from our response, both its successes and its shortcomings. That leads to one of the overall recommendations of this paper: once the crisis is brought under control, every government, including the New Zealand Government, ought to set up a special committee or investigatory body or commission to examine their COVID-19 response, in all respects, and to compare that response with that adopted by other countries.

This pandemic is a wake-up call for all citizens: they have to scrutinize what their government does in their name, or it could cost them their lives. It is suggested that the investigatory body should consist of political actors from all parties but experts from all affected sectors, especially from the health, legal, education, tourism, customs, immigration and police sectors. The investigatory body should have the remit to produce an independent investigation and report — which should be made publicly available — on all aspects of the Government's response, including the legal, constitutional and economic dimensions of its response.

The COVID-19 pandemic was sudden and unexpected for most, but there is no one who will be able to say that we "weren't warned" when the next pandemic hits. Indeed, even virologists from the Wuhan Institute of Virology warn that the current virus is just "the tip of the iceberg". ${ }^{166}$ So, we can expect future pandemics and we should take this opportunity to learn from our mistakes by reviewing all of our Governments' actions openly, transparently and critically in the spirit of learning from our errors so that they are not repeated.

Although the focus has been on the New Zealand Government's response, the COVID-19 pandemic has underlined how interconnected we are as countries and as individuals. Just think: a handful of people were infected in Wuhan, China in December 2019 and six months later there are 5,402,607 confirmed cases and 344,981 deaths worldwide...and rising. ${ }^{167}$ This paper has attempted to weave in comparisons via a comparative law thread because now, more than ever, it is important for countries to look at how they have each responded to the crisis, with a critical eye, and compare their response with other countries to identify similarities and differences, strengths and weaknesses.

166 Gavin Fernando, "COVIOD-19 Coronavirus: Wuhan scientists says new virus 'is just the tip of the iceberg" NZ Herald/news.com.au 26 May 2020, available at: <https:/www.nzherald.co.nz/world/ news/article.cfm?c_id=2\&objectid=12334844>.

167 World Health Organization "Coronavirus disease (COVID-19) Situation Report 96" 25 April 2020 available at: < https://www.who.int/docs/default-source/coronaviruse/situation-reports/20200425sitrep-96-covid-19.pdf?sfvrsn=a33836bb_2>. 
Furthermore, we as academics, all encourage our students to develop their critical thinking skills, to never accept anything without independently assessing its accuracy and legitimacy; we must also use that critical lens to assess how well our governments have served us during this extraordinary time. We must employ our critical thinking skills, our experience, our legal and other specialist knowledge, to cast a critical eye on all of our governments and ask whether their actions were appropriate and whether they passed the COVID-19 stress-test for democracy.

Finally, it is prescient to remember that Reverend Theodore Parker used a wonderful phrase to describe the essence of democracy when he delivered a sermon on slavery at the Boston Music Hall on 4 July $1858 .{ }^{168}$ Later, Abraham Lincoln apparently read these same words and underlined some of them (the ones highlighted below). Parker wrote that:

Theocracy, the priest power, monarchy, the one-man power, and oligarchy, the few-men power, are three forms of vicarious government over the People, perhaps for them, not by them. Democracy is direct self-government, over all the people, by all the people, for all the people. Our institutions are democratic: theocratic, monarchic, oligarchic vicariousness is all gone.

Those highlighted words of Parker's made their way into the Gettysburg Address and they have since become synonymous with the concept of democracy the world over. ${ }^{169}$ On the basis of Lincoln's conception of democracy, it is not disloyal, unpatriotic, and it is certainly not a crime, to look very closely at how our governments wield power. It is submitted that any government which opposes the people's scrutiny of its processes-of all its processes - especially during a crisis such as the current one (when it wields even more power than usual) loses its claim to be a government of the people, by the people, for the people and it can no longer make any claim on the notion of democracy.

168 Theodore Parker "The effect of slavery on the American people: a sermon preached at the Music Hall, Boston, on Sunday, July 4, 1858" The Anti-Slavery Collection from Oberlin College, available at: <https://archive.org/details/ASPC0001893300/mode/2up>, PDF of the sermon available here: $<$ https://ia802509.us.archive.org/17/items/ASPC0001893300/ASPC0001893300.pdf>.

169 President Abraham Lincoln "The Gettysburg Address" Delivered on 19 November 1863 at Gettysburg, Pennsylvania, text available at: <http://www.abrahamlincolnonline.org/lincoln/speeches/gettysburg. $\mathrm{htm}>$. The famous three-part phrase, " this government, of the people, by the people, for the people, shall not perish from the Earth" written by Lincoln appears in all five copies of the Gettysburg Address (that is, the Bliss, Nicolay, Hay, Everett and Bancroft copies). 


\section{Table of Contents}

\begin{tabular}{|c|c|}
\hline Subject & Page \\
\hline Abstract & 55 \\
\hline Introduction & 56 \\
\hline $\begin{array}{l}\text { Section 1. An introduction to New Zealand and its constitutional } \\
\text { framework }\end{array}$ & 59 \\
\hline Total population and ethnicity & 60 \\
\hline Population distribution & 61 \\
\hline Population density & 61 \\
\hline Age distribution & 61 \\
\hline Overview of our constitutional arrangements & 62 \\
\hline Section 2. An overview of the New Zealand Government's response & 63 \\
\hline A travel ban on arrivals from China and other measures & 64 \\
\hline The 4-tiered Alert Level System & 66 \\
\hline $\begin{array}{l}\text { Analysing the effectiveness of the New Zealand } \\
\text { Government's response }\end{array}$ & 70 \\
\hline $\begin{array}{l}\text { Economic impact and response of COVID-19 and the } \\
\text { lockdown }\end{array}$ & 75 \\
\hline $\begin{array}{l}\text { Section 3. Declaration of a State of National Emergency \& its } \\
\text { Statutory Basis }\end{array}$ & 75 \\
\hline $\begin{array}{l}\text { Section 4. Adjourning Parliament: Establishing the Epidemic } \\
\text { Response Committee }\end{array}$ & 81 \\
\hline $\begin{array}{l}\text { State of emergency notified to the House of } \\
\text { Representatives and Epidemic Notice issued }\end{array}$ & 83 \\
\hline $\begin{array}{l}\text { Laws passed to secure Government's COVID-19 related } \\
\text { expenditure }\end{array}$ & 84 \\
\hline
\end{tabular}




\begin{tabular}{|l|c|}
\hline $\begin{array}{l}\text { Epidemic Response Committee in lieu of a siting } \\
\text { Parliament }\end{array}$ & 86 \\
\hline $\begin{array}{l}\text { Critique of the Government's response } \\
\text { The United Kingdom: Parliament in recess }\end{array}$ & 88 \\
\hline $\begin{array}{l}\text { Australia calls for a New Zealand-style COVID-19 } \\
\text { committee }\end{array}$ & 91 \\
\hline $\begin{array}{l}\text { Section 5. The role of the media in holding the Government to } \\
\text { account }\end{array}$ & 92 \\
\hline $\begin{array}{l}\text { Freedom of expression and COVID-19: the good, the } \\
\text { bad and the ugly }\end{array}$ & 93 \\
\hline $\begin{array}{l}\text { Democracy and disability } \\
\text { Section 6. Conclusion and recommendations }\end{array}$ & 101 \\
\hline
\end{tabular}


